\title{
Çalışan Kadınlarda Şiddet Algısı ve Bu Algıda Ekonomik Şiddetin Yeri
}

\author{
Violence Perception of Working Women and the Role of Economic Violence in this Perception
}

\author{
Rabia İNCí \\ Yüksek Lisans Öğrencisi, Karabük Üniversitesi, \\ S.B.E., Sosyal Hizmet A.B.D., \\ rabiainci.95@gmail.com \\ https://orcid.org/0000-0002-4270-3658
}

Makale Başvuru Tarihi: 21.07.2019

Makale Kabul Tarihi: 02.04.2020

Makale Türü: Araştırma Makalesi

\section{Anahtar \\ Kelimeler:}

Şiddet,

Ekonomik Şiddet,

Çalışan Kadın,

\section{Keywords:}

Violence,

Economic Violence,

Working Woman,

\section{ÖZET}

Toplumun temel yapısını "aile" oluşturmaktadır. Toplumda aile sistemi bozulduğunda diğer sistemler de işlevsiz hale gelebilmektedir. Ekonomik şiddet ise aile dengesini bozan en önemli unsurlardan biridir. Kadınların çalışma yaşamına girmesi, ekonomik şiddeti engelleyememektedir. Erkeğin ekonomik kazanç üzerindeki tahakkümü ailede işçi-işveren ilişkisini ortaya çılkarabilmekte bu durum sonucunda sağllklı olmayan evlilikler ortaya çıkarak boșanma oranları artabilmektedir. Araștırma, çalıșan kadınlarda ekonomik şiddetin varlı̆̆ ve ekonomik şiddetin kadınlar üzerindeki etkisini değerlendirmek amacıyla Karabük İlinde ikamet eden 10 çalışma deneyimi olan kadınla görüşülerek gerçekleştirilmiştir. Çalışma nitel bir araştırma olup çalışmada yarı-yapılandırılmış mülakat tekniği kullanılmıştır. Betimsel analiz ve içerik analizi yoluyla veriler bilgisayara aktarılmıştır. Bulgulara göre katılımcılar tarafindan şiddet; fiziksel ve psikolojik olarak algılanmaktadır. Ekonomik şiddet olgusu katılımcılar tarafindan fazla bilinmemektedir. Çalışan kadınların yaşadığ ekonomik şiddet kadinları olumsuz yönde etkilemekte yaşam kalitesi ve yaşam doyumunu azaltabilmektedir. Aile içi ekonomik şiddet; kadını yoksullaştırabilmektedir. Çalışan kadınlar ekonomik bă̆ımsızlı̆̆ını elde etse de ekonomik gelirini harcamada yeterince özgür olamamaktadır. Bu noktada erkeğin baskısı kadını daha da çıkmaza sokabilmektedir. Çalışan kadınların yaşadığı ekonomik şiddet neticesinde kadında depresyon, intihar eğilimi, sosyal izolasyon gibi psiko-sosyal sorunlar ortaya çıkabilmektedir. Aynı zamanda ekonomik şiddet, kadınların iş motivasyonunun düşmesine hatta iş kaybına da sebep olabilmektedir. Kadının psiko-sosyal-ekonomik ihtiyaçlarının ihmali duygusal, fiziksel ve ekonomik şiddet olgusunu daha da tetikleyebilmektedir. Toplumda ekonomik şiddetin varllğı noktasında bilinçlendirme çalışmaları yapılmall, farkindalık arttırlmalıdir.

\begin{abstract}
The family is fundamental structure of society. If the family system is corrupted, the other systems might be functionless. Economic violence is the most important factor which break down the family equilibrium. Women participation in business life can prevent the economic violence. Domination of men on economic profits lead to employer lemployee relations in family, resulted in unhealthy marriages. This sitations cause to increase divorce rate. This researh was conducted with interviewing with 10 women, who has work experience and has accommodated in the city of Karabuk to evaluate economic violence effect on women. This study is a qualitative research and semi-structured interview technique was used. Data transferred to computer through descriptive analysis and content analysis. Violence is perceived physically and psychologically by the participants according to findings. The phenomenon of economic violence is not well known by the participants. Economic violence has affected negatively women who is working and decreased quality of life and life satisfaction. -Domestic economic violence might impoverish women. Even if working women gain economic independence, they are not free enough to spend their economic income. At this point, the pressure of the man puts the woman in a deadlock. As a result of-, the economic violence, women might experience some psycho social problems such as depression, suicidality, social isolation, drug addiction. At the same time, economic violence might resulted in women job motivation decrease, even job lose. Neglect of women psycho social economic needs might trigger emotional, physical and economic violence phenomenon. Awareness activities should be done about the existence of economic violence in society and awareness level shold be increased.
\end{abstract}




\section{GIRISS}

Kadının çalışma yaşamı ve kadına yönelik şiddet güncelliğini koruyan önemli bir konudur. Geçmişe baktığımızda kadınlar, üretimin her aşamasına katkıda bulunmuşlardır. Eşitlikçi bir anlayışla devlet politikaları kadın istihdamını desteklemiş ve bu konuda özendirme çalışmaları gerçekleştirmiştir. Erkek ve kadının cinsiyetlerinden bağımsız bir şekilde eşit sorumluluk, firsat ve olanaklara sahip olabilmesi toplumsal cinsiyet eşitliğini ifade etmektedir. Sürdürülebilir kalkınmanın gerçekleştirilmesinde ve sosyal refahın gelişiminde kadınların işgücüne aktif katılması önem arz etmektedir. Kadın toplumsal yaşamda birçok rolü üstlenmektedir. Özellikle aille içinde eş ve anne rolünü üstlenen kadın, bu rolleri çalışma yaşamındaki mesleki rolle sürdürebilmektedir. Bu rolleri büyük bir özveriyle üstlenen kadın, aile içerisindeki diğer üyeler tarafindan gerekli anlayış ve desteği görmediği takdirde kendini değersiz hissetmekte ve örselenebilmektedir. Bu durum sonucunda aile içinde çatışma ve krizin ortaya çıkması kaçınılmazdır. Çatışma ve kriz ise içeriğinde şiddeti barındırmaktadır. Dünyada temel insan hakları ihlali olarak varlığını devam ettiren "kadına yönelik şiddet", kadınların fiziksel ve mental sağlığını bozmaktadır. Şiddet; kadınların ekonomik, sosyal, kültürel statülerini düşüren ciddi bir psiko-sosyal sorundur.

Kadına yönelik şiddetle ilgili yapılan çalışmalar hem küresel boyutta hem de ülkemizde sorunun ciddiyetini gözler önüne sermektedir. Dünya'da şiddet oranlarına bakıldığında, örneğin, Kuzey Hindistan'da yaşayan kadınların \%17'sinin fiziksel şiddete, \%22'sinin cinsel şiddete maruz kaldığı diğer yandan Doğu Londra'da kadınların \%61'inin aile içi şiddete, \%87'sinin ise cinsel şiddete maruz kaldığı saptanmıştır. Nikaragua'da yaşayan kadınların \%52'sinin şiddet gördüğ̈̈, Japonya'da ise kadınların \%67'sinin fiziksel şiddete maruz kaldığı bulunmuştur. Ayrıca Washington'da yapılan bir araştırma da ise kadınların \%27'sinin eşlerinden veya birlikte oldukları kişiler tarafından fiziksel şiddete maruz kaldığı saptanmıştır (Köse ve Beşer, 2007:115). Şiddet denilince ilk akla gelen fiziksel şiddet olsa da ekonomik şiddetin de sonuçlarının yıkıcı olduğu göz ardı edilmemesi gerekmektedir.

Ekonomik şiddet, kadınların maruz bırakıldığı psikolojik, fiziksel, cinsel şiddet türlerini etkilemekte, hatta bunların önemli bir nedenini de oluşturmaktadır. Çünkü ekonomi, gücü ve iktidarı simgeleyen hatta sosyal yapıdaki etkileşimleri oluşturan, biçimlendiren bir niteliğe sahiptir (Gökkaya, 2011:104). Ekonomik bask1 ve şiddet; hem şiddetin kaynağını hem de sonucunu oluşturabilmektedir.

Birçok toplumda kadına yönelik şiddet herkes tarafından kabul gören bir davranış olarak algılanmakta ve evliliğin olağan bir özelliği olarak bilinmektedir. Kadının şiddete bakış açısı yaşadığı toplumun kültürüne, mevzuata, kadının eğitim ve sosyo-ekonomik düzeyine göre değişmektedir (Subaşı ve Akın, 2016:6). Kadınlar, toplumsal cinsiyet eşitsizliğin de etkisiyle en yakınları tarafindan ekonomik şiddete maruz bırakılmaktadır. Kadının iş yaşamında aktif olması onu bu şiddetten alıkoyamamaktadır. Ekonomik şiddet, çalışan kadınlarda ve çalışmayan kadınlarda farklı şekilde tezahür etmektedir. Ekonomik şiddet çalışmayan kadınlarda, harçlık vermeme veya yeterince vermeme, kadınının maddi ihtiyaçlarının karşılanmaması, kadının çalışmasına izin verilmemesi gibi durumlarla ortaya çıkarken çalışan kadınlarda ise maaşınave maaş kartına el koyma, maaşı dilediğince harcayamama, ev işleri sorumluluğunda kadını desteksiz bırakma gibi durumlarla ortaya çıkabilmektedir. Kadın, çalışsa da çalışmasa da aile içinde dezavantajı konuma düşmektedir. Bu konuyla ilgili kadınlar şiddeti aile içi özel bir durum olarak görmekte ve şiddet olgusunu kimseyle paylaşmak istememektedir. Kadınlar, ekonomik şiddeti "şiddet" olarak algılamakta zorlanmakta bu durumun olağan, süregelen bir şekilde geliştiğine inanabilmektedir. Bu anlayışın yıkılması için "ekonomik şiddet danışma birimleri”"ne ve ekonomik şiddetin ne olduğunu, sonuçlarını açıklayacak ve ekonomik şiddetin önlenmesi adına rehberlik ve farkındalık çalışmaları yapabilecek sosyal hizmet uzmanlarına ihtiyaç vardır. Bu çalışmada son yıllarda literatüre giren ekonomik şiddet, çalışan kadınlar açısından ele alınarak çalışan kadınların ekonomik şiddet algıları incelenmiştir. Araştırmanın kadınlara yönelik hedefi; çalışan kadınlarda şiddet bilincini oluşturmak ve çalışan kadınların aile içinde şiddete dair gerekli önlem alınması ve müdahalede bulunmaları konusunda adım atılmasıdır. Şiddet, kadınların karşısına iş yerinde, evlerinde, sosyal hayatlarında karşılarına çıkabilmektedir. Şiddetin bir türü olan kadına yönelik ekonomik şiddettin hayatın her aşamasında karşılaşılabilecek bir boyutta olması, onunla olan mücadelenin de her boyutta yapılması gerektiğini ortaya koymaktadır. Şiddeti önleme çalışmaları ve şiddete uygun müdahale uygulamaları refah toplumunun sürdürülebilirliği açısından önemli bir role sahiptir. Bu bağlamda çalışmanın amacı; kadına yönelik ekonomik şiddet sorunun farkındalığını artırmak, bu kapsamda da önleyici ve müdahaleci çalışmalara akademik katkı sağlamaktır. 


\section{KAVRAMSAL AÇIDAN KADINA YÖNELİK ŞIDDET}

Kadına yönelik şiddet; kadınlarda psikolojik, ekonomik, fiziksel ya da cinsel etkileri oluşturan ya da oluşturmaya yönelik, kadınların şahsi veya sosyal hayatlarında gerçekleşebilen ve sonrasında da uzun bir süre şiddete maruz kalan kadın üzerinde etkileri süren her türlü baskı, davranış, tehdit içeren hareketlerdir (Öztürk vd., 2016:140). Kadına yönelik şiddetin amacı; kadının davranışlarına müdahale ederek üzerinde bir tahakküm oluşturmaktır. Bu anlamda kadına yönelik şiddet olgusu, kadını kontrol etmek amacıyla ve kadının isteği dışında gerçekleşen eylemler olarak tanımlanabilmektedir. Şiddet olgusunda gözlemlendiği gibi kadına yönelik şiddet eylemleri de sadece fiziksel değil duygusal, ekonomik, cinsel şiddet şeklinde meydana gelebilmektedir (Uluocak vd., 2014:370).

Özel yaşam ve kamu yaşamında kadına yönelik şiddetin izleri görülmektedir. Kadınlar en fazla aile içinde şiddete maruz bırakılmaktadır. Aile hayatında yaşanılan şiddet özel/kişisel olarak algılanıp toplumla paylaşılmak istenmemektedir. Kamu yaşamında uygulanan şiddette ise toplum sorumlu tutularak gündem oluşturabilmektedir (Gökkaya, 2009:169).

Ataerkil toplumlarda, kadına yönelik şiddetin meşru gerekçesi olarak görülen erkeğin sinirlendiği zaman kadına ceza verebilmesidir. Bu durum yalnızca erkekler tarafından değil kadınlar tarafindan da meşru görülmektedir (Krug vd., 2002:93). Sosyal roller, sosyal statü, özgüven eksikliği, baskı, sosyal çevre baskısı ve ekonomik baskının etkisiyle kadınlar şiddet gördüğ̈̈ hanede mutsuz olma pahasına evliliklerini sürdürmektedir (Harcar vd., 2008:60). Bu durum sağlıklı evlilik ve aile ilişkilerinin oluşumunu engelleyebilmektedir.

Tauchen vd. (1991) yaptıkları çalışmada, düşük ve orta gelirli ailelerde erkeğin kadına şiddet eğilimli ve kontrol davranışının doğru orantılı olarak daha çok arttığı, gelir düzeyi daha yüksek ailelerde ise; her iki tarafın da ilişkiden memnun olduğu bulgusuna ulaşmıştır. Ancak çalışma, hem kadının hem erkeğin çalıştığı durumlarda kazandıkları paranın miktarına ve evlilik içinde paranın eşler arası paylaşımının nasıl yapılacağına göre de şiddetin derecesinin artıp azalmakta olduğunu, dolayısıyla aile içi şiddetin dışarıda çalışma ve ekonomik gelir kazanmakla doğrudan bağlantılı olduğunu göstermiştir. Dolayısıyla bu şiddet, kadının çalışmayıp eşine bağımlı olduğu, çalışıp eşinden az kazandığı veya daha çok kazandığı, kocanın çalışmadığı veya çalışıp da sözü edildiği gibi gelir seviyesinin kadının gelirine göre farklılık gösterdiği durumların kombinasyonuna göre farklılık göstermektedir (Harcar vd., 2008:61). Kadının ekonomik kazanç elde etme ile aile içi şiddete maruz kalması arasında anlamlı bir ilişki kurulabilmektedir.

Kadınların sosyal hayatta çalışması onlara bireysellik getirmektedir. Hem evde hem de sosyal hayatta çalışarak yaşamını sürdüren kadın, hak ettiği değeri maalesef ki görememektedir. Kadının ev içinde ezilmesi ve iş yaşamında mobbing gibi uygulamalara maruz bırakılması kadınının her iki taraftan da taarruz aldığının ve hayatının her alanında şiddetle karşılaştığının en önemli göstergesidir (Demirer, 2007:92).

Sürekli eş ve anne roller öne çıkarılan atif işgücüne katılan kadınlarda mesleki rol ikinci plana itilmektedir. Çalışma yaşamının ve ev yaşamının getirmiş olduğu rol ve sorumluluklar ise kadını kaygı düzeyini arttırmakta, onu duygusal anlamda çöküntüye sürüklemektedir. Kadın, aile hayatını odak noktası yapıp, işini ikinci plana atarsa işinde ikinci sınıf çalışan olacak, eğer işini ilk sıraya koyup, ailesini ikinci plana atarsa da sahip olduğu geleneksel roller olan eş ve annelik rolleriniyerine getiremeyerek, iyi anne iyi eş olamayacaktır. Dolayısıyla bu durum, onu çıkmaza sokmakta ve duygusal çöküntüye uğramasına sebep olmaktadır (Gökkaya, 2011:107). Kadın, hem aile içi rol ve sorumluluklarını yerine getirip hem de iyi bir kariyer sahibi olabilmek için kendi emel ve arzularından taviz verebilmektedir.

\subsection{Kadına Yönelik Ekonomik Şiddet}

Ekonomik şiddet; paranın ve ekonomik kaynakların kadın üzerinde bir tehdit, yaptırım, baskı, kontrol etme aracı olarak kullanılmasıdır (Gürkan ve Coşar, 2009:125). Kadına yönelik ekonomik şiddet göstergeleri arasında Kadının az gelirli ve statüsü düşük işlerde çalışmasına mecbur bırakmak, kadının aile içerisinde ücretli işçi muamelesi görülerek değersizleştirilmesi, kadın çalışıyorsa maaşına el konulması (Banka kartın zorla elinden alınması), kadınların takılarına, paralarına ve mallarına el konulması, kadının istediği halde çalışma yaşamına girmesine izin verilmemesi, kadının mirastan yoksun bırakılması, kocanın eve yeterli miktarda para bırakmaması, ailenin gelir-gideri (gelir-gider muhasebesi) hakkında ve gelirin nerede tutulduğu hakkında kadına bilgi verilmemesi veya eksik bilgi verilmesi, kadına boşanma sonrasında nafaka ödenmemesi, kadının para 
karşılığında satılması ve kadının seks işçiliğine zorlanması, kadının sosyal güvenceden yoksun bırakılması ile işgücü piyasasında yaşanılan cinsiyet eşitsizlikleri ele alınmaktadır (Gökkaya, 2011:373).

Ekonomik şiddet göstergeleri ülkemizdeki birçok kadın üzerinde görülmektedir. Çalışan kadınlar üzerindeki ekonomik şiddet göstergeleri ele alındığında kadının çalışma yaşamına girmesi ve ekonomik kazanç elde etmesi en çok akrabaları ve aile üyeleri tarafından engellenmektedir. Bazı ailelerde ailenin geçimini sürdürme sorumluluğu kadına yüklenmektedir. Kadın zoraki bir şekilde istemediği bir işte çalıştırılmaktadır. Kadının maaşı zorla elinden alınmaktadır ve kadın aynı zamanda evdeki işleri maddi karşılık beklemeden yapma zorunluluğu içerisinde kalmaktadır.Kadınlar ev işerini düzenli olarak ailenin huzuru için yapsa da aile içinde takdir görmemektedir (Eşkinat, 2013:292).

Ekonomik faktörün şiddet ilişkisindeki işlevselliği iki yönlü olduğuna dikkat çeken İçli (1994)'ye göre, ya kadın ekonomik açıdan erkeğe bağımlıdır ya da mesleki statü açısından erkekten üstündür. Bu ikinci durumda erkek kadını tehdit unsuru olarak görmektedir. Türkiye'de 15-49 yaş grubundaki kadınların \%39'u kadının parayı gereksiz bir şekilde harcaması durumunda kocanın karısına fiziksel şiddet uygulama hakkı olduğunu belirtmiş̧ir (TNSA, 2003:41). Kadına yönelik ekonomik şiddetin, bu şiddeti yaşayan kadınlar tarafından önemli bir oranda (\%39) kabullenildiği görülmektedir. Önemli bir kadın grubunun bu düşünceyi kabullenmiş olması, kadına yönelik ekonomik şiddetin de meşrulaşabilmesine olumsuz katkı sağladığı düşünülmektedir. Bu durum esasen toplumsal hayatta ekonomik şiddete maruz kaldığını fark etmeyen birçok kadının yaşadığı kanaatini ortaya koymaktadır.

Ekonomik ve sosyal kalkınmanın önündeki en büyük engellerden biri ekonomik şiddettir (Köse ve Beşer, 2007:118). Ekonomik kazancın çok iyi olması kadının refah içinde yaşamasına neden olur ve şiddet görme oranı azalır denilebilir. Ancak "ters tepki hipotezi" bu duruma farklı bir şekilde yaklaşmaktadır. Ters tepki hipotezine göre “özgürlüğ̈̈ ve statüsü artan kadının şiddete uğrama oranı yükselmektedir"(Riger ve Krieglstein, 2000:635). Statüsü ve özgürlüğü artan kadın; ekonomik bağımsızlığı elde etse de eş tarafindan uygulanan ekonomik şiddete maruz kalabilmektedir. Aile içi kriz ve çatışma dönemlerinde ekonomik şiddet etkilerini fiziksel ve duygusal şiddetle birlikte gösterebilmektedir.

Kadının mesleki ilerlemesini engellemek veya çalışma hayatından yoksun bırakmaya çalışmak ekonomik şiddeti tetikleyen unsurlardır. İyi çocuk yetiştirme, ev sorumluluğunu eksiksiz yerine getirme amacıyla da bu şiddet uygulansa kadın kendini gerçekleştiremediği için mutsuz olacak ve bu mutsuz olma durumu çocuk ve eş iletişimine zarar verebilecektir.

\subsection{Ekonomik Şiddetin Kadın Üzerindeki Etkisi}

Şiddeti yalnızca "fiziksel saldırganlık ve zarar" olarak açıklamak yeterli değildir. Bilişsel ve ekonomik boyutlarıyla da bireyde ya da toplumda değişken sürelerde veya kalıcı olarak etkileri olabilmektedir (Atman, 2003:333). Kadınların ekonomik, psikolojik, cinsel ve fiziksel şiddet görme olasılıklarını etkileyen faktörler değişken olsa da, ön plana çıkan asli faktörler de mevcuttur. Kadına yönelik şiddeti ortaya çıkaran temel etmenler; kadının yaşı, kadının ve eşinin eğitim düzeyi, sağlık durumu, ailenin etkisi, kadının yaşadığı yer, çocuklukta aile içi şiddete maruz kalma durumu, evlenirken kadının rızasının alınıp alınmaması durumu, akraba evliliği yapması, kadının çocukluğunda istismara uğraması, kadının aldatılması, eşin alkol bağımlısı olması, eşin kumar alışkanlığının bulunması, eşin çalışması, intihar düşüncesi/intihar girişiminde bulunma ve sosyal güvenliğinin olup olmaması şeklinde açıklanmaktadır (Çalışkan ve Çevik, 2018:228).

Toplumsallaşma sürecinde ön planda olmaması, elindekilerle yetinerek kanaat etmesi veya ekonomik özgürlükten mahrum bırakılması öğretilen kız çocukları, çoğunlukla eğitim anlamında geride bırakılarak çalışma hayatına sokulmamaktadır. Eğitimden mahrum bırakılan ya da eğitim eksikliği olan kadınların ev içinde de emeği sömürülmekte, ev eksenli çalıştırılmakta ve maddi özgürlük yaşayamamaktadırlar (Gökkaya, 2011:104). Kaç çocuğa sahip olacaklarına karar verme, çocuğun eğitimi ile ilgili kararların alınmasında yer alma, vd. aile içi karar alma süreçlerinde kadının etkisinin artmasında ekonomik bağımsızlığının etkisi oldukça fazladır. Kadındaki ekonomik güç iki farkı sonuçla karşımıza çıkmaktadır. Birincisi; kadınının ekonomik gücü arttıkça daha az şiddet göreceği konusundadır. İkincisi ise; kadının ekonomik kazancı arttığında eşinin fikirlerine daha fazla muhalif olması sonucunda daha fazla şiddete maruz kalacağıdır. Ekonomik özgürlüğe sahip olan kadınlar sağlıklı olmayan bir birlikteliği bitirme veya hiç evlenmeme kararı verebilmektedir. Ayrıca bu duruma aykırı olarak kadının çalışması erkeklerin kendini yetersiz hissetmesine sebep olarak, kadının şiddete uğramasına yol açabilecektir (Hindin ve Adair, 2002'den akt.: Dindaş, 2008:19-20). 
Guljan vd. (2012) tarafından İzmir'in Konak İlçesi'nde bulunan 25-49 yaşları arasındaki kadınların maruz kaldığ psikolojik şiddet sıklığ $\% 93$, fiziksel şiddet $\% 37.5$, ekonomik şiddet $\% 34.4$, cinsel şiddet $\% 3.9$ düzeyinde olduğu ortaya çıkmıştır. Psikolojik şiddete maruz kalma durumu, ortaokul ve üzeri öğrenimli kadınlarda daha fazla olduğu saptanmıştır. Erkeklerin işinin olmaması veya düzensiz işlerde çalışması, alkol kullanımı alışkanlığının olması, istenmeyen gebeliğin varlığı ve kadının 25-34 yaş grubunda olması fiziksel şiddette en belirleyici etmenler olarak saptanmıştır. Çalışma sonucuna göre; üç erkekten birinin eşlerine ekonomik ve fiziksel şiddet uyguladığı ortaya çıkmıştır.

Dillon vd. (2013), eş şiddetine maruz kalan kadınların fiziksel ve zihinsel sağlıkları arasındaki ilişkiyi ikincil kaynakları kullanarak incelemişlerdir. Çalışmaları 2006'dan 2012'ye kadar yayınlanan gözden geçirilmiş araştırma raporları ile gelişmekte olan ülkelerin nicel ve nitel araştırmalarını içermektedir. 75 bildirinin yer aldığı derlemenin sonuçlara göre, kadına yönelik aile içi şiddeti; depresyon, kaygı, intihar girişimi ve uyku bozuklukları gibi bir dizi sağlık sorununu arttırmaktadır. İncelenen birçok çalışmada, bu etkiler doğrulanmış ölçüm araçları kullanılarak gözlemlenmiştir. Ayrıca kadına yönelik eş şiddetini genel sağlık, kronik bozukluklar, kronik ağrı ve jinekolojik rahatsızlıklar ile ilişkili olduğu saptanmıştır.

2018 yılında yapılan araştırma sonuçlara göre, kentte yaşayan kadınların kırda yaşayanlara göre ekonomik şiddete uğrama olasılığının daha düşük (yaklaşık \%56 daha az) olduğu tespit edilmiştir. Yine aynı çalışmada kadınların eğitim düzeyi arttıkça ekonomik şiddet görme olasılığının da arttı̆̆ görülmüştür (Çalışkan ve Çevik, 2018:226). Bu sonuç teorik görüşler ile uyumludur. Çünkü ekonomik şiddetin gelir ile ilişkili olduğu birçok araştırma ile ortaya konulmuş genel bir sonuçtur. Eğitim düzeyi arttıkça da çalışan kadın sayısı ve kadınların gelir düzeyleri de artmaktadır. Bu bağlamda eğitim düzeyinin artması ekonomik şiddeti arttırıcı bir etkiye sahip olabilmektedir. Diğer taraftan çocuk sayısının artması kadınların ekonomik şiddet görme olasılığını azaltıcı yönde bir etki yapmaktadır. Sosyal güvencesi olan kadınların, sosyal güvencesi olmayan kadınlara nazaran \%19 oranında daha az ekonomik şiddete maruz kaldıkları aynı çalışma ile tespit edilmiştir. Çalışmada yine kendi rızası alınarak evlenen kadınların, rızası alınmadan evlenenlere oranla daha az ekonomik şiddete maruz kaldıkları sonucuna ulaşılmıştır. Diğer taraftan akraba evliliği yapan, aldatılan ve çocukken tacize uğrayan kadınların ekonomik şiddet görme olasılıklarının anlamlı şekilde arttığı görülmektedir. Ekonometrik model sonuçları çocukken aile içi şiddete maruz kalan kadınların daha az ekonomik şiddet gördüklerini belirtmekte ve bu sonuç kadınların farkındalık durumuyla açıklanabilmektedir. Diğer bir ifadeyle, çocukken ailede şiddete maruz kalan kadınların bu durumu daha önce tecrübe etmesine istinaden proaktif davranış sergilemesine neden olabilmektedir. İntihar düşüncesinde olan ve intihar girişiminde bulunan kadınların ekonomik şiddet görme olasılıklarının daha fazla olduğu (sırasıyla 1.4 ve 1.8 kat) sonucu ortaya çıkmıştır. Kuşkusuz burada net olarak bir neden-sonuç ilişkisinin kurulması oldukça zordur. Çünkü şiddete maruz kalan kadınların da intihar eylemi ve girişiminde olması beklenebilmektedir. Eş ile ilgili sorularda eşin eğitim düzeyi ve kumar oynaması istatistiksel olarak anlamlı bulunmuş ve eşin eğitim düzeyi arttıkça kadınların ekonomik şiddet görme olasılığı düşerken, eşi kumar oynayan kadınların daha fazla ekonomik şiddete maruz kaldıkları sonucuna varılmıştır. Son olarak, ekonomik şiddetin gerekçesi olarak sadece aile kaynaklı nedenler istatistiksel olarak anlamlı bulunmuştur (Çalışkan ve Çevik, 2018:226).

Yapılan çalışmalardan ve araştırmalardan elde edilen genel sonuçlara göre şiddete uğrayan kadınların yaşam kalitesinin azalması ve ruhsal çöküş yaşayabilmeleri olasılıklarının yüksek olduğu görülmektedir. Bunun neticesinde ise şiddete uğrayan kadınların sağlık ve sosyal hizmetlere olan ihtiyaçları artabilmektedir. Şiddete maruz kalan kadınlarda; depresyon, travma sonrası stres bozukluğu, intihar girişimleri, çocuklarına yönelik saldırgan tutum, alkol ve madde bağımlılığı sık görülen durumlar olabilmektedir. Başlangıçta şok ya da hissizlik şeklinde tepkilere yol açan şiddet, tekrar aynı durumların yaşanma olasılığı fikriyle anksiyeteye yol açabilmektedir. Şiddetin sürekli olduğu durumlarda ise umutsuzluk, çaresizlik, benlik saygısında azalma, suçluluk güvensizlik, ve kontrolün kaybedildiği duygusu görülebilmektedir. Kadınlar ekonomik şiddeti bir süre sonra içselleştirmeye başlayarak yaşamın gereği olarak algılayabilmektedir. Toplumumuzda bu algı maalesef ki çok yaygın olmakla birlikte bu algının değişebilmesi için yeterli çalışmaların yapılmadığı kanaatine var1lmaktadır (Stewart ve Robinson, 1998; Bonomi vd., 2006; Kernic vd., 2003; Who, 2005'lardan akt.: Han Almış vd., 2018:68). 


\section{3. ÇALIŞAN KADINLARDA ŞIDDET ALGISI VE BU ALGIDA EKONOMIKK ŞİDDETİN YERİ}

\section{1. Çalışmanın Konusu, Amacı ve Önemi}

Çalışmanın konusunu aktif işgücüne katılmış olan olan kadınların şiddeti algılama biçimleri ve bu kadınların aile içinde yaşadığı ekonomik şiddetin yaşamlarına etkisi oluşturmaktadır. Çalışmanın amacı; toplumda ekonomik şiddetin yaygınlığı hakkında farkındalık oluşturmak ve bu konuda toplumun bilinçlenmesi için katkıda bulunmaktır. Kadına yönelik şiddet vakaları her geçen gün artmakta ve kamuoyunda gündemini korumaktadır. Bu nedenle de kadına yönelik şiddet ve bu şiddetin bir alt türü olan ekonomik şiddet üzerinde özverili bir şekilde çalışmaların artarak devam etmesinin konuya olan ilginin daha çok arttıracağ düşünülmektedir. Buradan hareketle de kamuoyunda daha çok tartışılan, çözüm önerilen ve uygulanan bir olgu olacağı düşünülmektedir. Bu bağlamda çalışmanın akademik yazına ve çözüm odaklı çalışmalara katk1 sağlayacağına inanılmaktadır.

\section{2. Çalışmanın Yöntemi}

Çalışan kadınların şiddet algısının ölçülmeye çalışıldığı ve çalışan kadınların ekonomik şiddet ile ilgili görüşlerinin alındığı bu çalışma nitel bir araştırmadır. Nitel araştırma; "gözlem, görüşme ve doküman analizi gibi nitel veri toplama tekniklerinin kullanildı̆̆l, algıların ve olayların doğal ortamda gerçekçi ve bütüncül biçimde ortaya konmasına yönelik nitel bir sürecin izlendiği araştırma", olarak tanımlanabilmektedir (Yıldırım ve Şimşek, 2008:5-15). Araştırmada ölçme aracı olarak yarı yapılandırılmış görüşme metodu kullanılmıştır. Yarı yapılandırılmış görüşme; verilerin hızlı kodlanmasına ve analiz edilmesine imkan tanıması, katılımcıların verdikleri bilgiler arasında benzerlik ve farklılıkları karşılaştırmaya yardımcı olması gibi özellikleri nedeniyle kullanılmıştır (Çepni, 2010:55). Katılımcıların çalışma hayatında aktif rol oynaması araştırma açısından önemlidir. Ulaşılabilirliği açısından Karabük’te ikamet eden kadınlar araştırmaya dahil edilmiştir.

\subsection{1. Çalışma Grubu}

Yapılan bu araştırmanın çalışma grubunu çalışma deneyimi olan Karabük'te yaşayan kadınlar oluşturmaktadır. Araştırmanın çalışma grubunun belirlenmesinde kartopu örnekleme yöntemi kullanılmıştır. Kartopu örnekleme; özellikle sık görülmeyen durumları incelemede bu özellikte bir bireyle temas kurulmasının ardından, bu bireyin yardımıyla diğer bir bireyle görüşüp zincirleme olarak örneklemi oluşturma işlemidir (Pagano ve Gauvreau, 1993:469-472). Araştırma, Karabük Üniversitesi Eğitim ve Araştırma Hastanesi'nde çalışan sosyal hizmet uzmanıyla görüşülerek başlatılmıştır. Ayrıca sosyal hizmet uzmanına yardım eden ilgili hemşire başta olmak üzere yakın ilişkili halkaya dahil toplamda 10 farklı çalışan kadın ile (K1, K2, K3, K4, K5, K6, K7, K8, K9, K10) yüz yüze görüşme sağlanmıştır. Her görüşmeciye eşit süreler tanınmaya çalışılmıştır. Ayrıca görüşme ortamındaki fiziksel koşulların da eşit olmasına dikkat edilmiştir. Görüşmecilere temel olarak aynı standart sorular yöneltilmiştir. Nitel bir çalışma yapıldığı için projenin kapsamı açısından görüşülecek kişi sayısı on kişi ile sınırlı tutulmuştur. Katılımcıların, konuyla ilgili sorulan sorulara doğru cevaplar verdikleri varsayılmıştır.

\subsubsection{Veri Toplama Aracının Geliştirilmesi}

Araştırmanın ilk aşamasında araştırmaya yönelik şiddet nedir? Kadına yönelik uygulanan şiddet türleri nelerdir? Ekonomik şiddet nedir? Ekonomik şiddet kadınları nasıl etkiler? Çalışan kadın mı yoksa çalışmayan kadın mı daha fazla ekonomik şiddete maruz bırakılıyor? Ülkemizde ve dünyada kadına yönelik şiddetin önlenmesine dair çalışmalar vb. durumların neler olduğu hakkında araştırma yapılmış ve gerekli literatür taranmıştır. Buna bağlı olarak araştırmada kullanılacak olan veri toplama aracı geliştirilmiştir. Araştırmada çalışan kadınların şiddet algisı ve bu algıda ekonomik şiddetin yerinin belirlenmesinde veri toplama aracı olarak yarı yapılandırılmış görüşme formu kullanılmıştır. Çalışan kadınların şiddet algısı ölçülmeye çalışılıp ve bu algıda ekonomik şiddetin yeri incelenmiştir. Veriler, kadınları tanıtıcı bilgi formu ve çalışan kadınlarla birebir görüşmeler ile toplanmıştır. Kadınlara sosyo-demografik bilgiler olarak yaş, eğitim durumu, meslek, evlenme yaşı, evlilik süresi, evlilik türü, eşin yaşı, eşin eğitim durumu ve eşin mesleği sorulmuştur. Şiddetin tanımı, hangi tür davranışların şiddetle ilişkilendirildiği, şiddetin kadın üzerinde fiziksel, ruhsal, ekonomik etkilerinin varlığı, ekonomik şiddetin nasıl algılandığı, eşin ekonomik şiddet uygulayıp uygulamadığı, eşin kadının çalışmasına nasıl baktığı, kadının ev işlerindeki katkısından dolayı eşin takdir etme durumu, maaş kartı kimin kullandığı, ekonomik şiddetin önlenebilme durumu değerlendirilmiştir.

Toplamda sekiz açık uçlu soru sorulmuştur. Katılımcılara öncesinde araştırmanın amacı ve önemi hakkında bilgi verilmiş ve gönüllülük esas alınarak katılımcılar araştırmaya dahil olmuşlardır. Veri elde etmek amacıyla 
kadınlara yöneltilen soruların açık ve anlaşılır olmasını sağlamak için uzman görüşlerine de başvurularak yarı yapılandırılmış görüşme formu hazır hale getirilmiştir.

\subsubsection{Verilerin Toplanması}

Araştırmaya ilişkin veriler, araştırmacı tarafından Karabük İlinde yaşayan gelişigüzel seçilmiş olan 10 çalışma deneyimi olan kadın ile yüz yüze iletişim kurmak suretiyle toplanmıştır. Araştırmacı, yapılan çalışmanın amacı ve içeriği hakkında bilgiler vermiş ve yapılan çalışmanın bilimsel bir çalışma olduğu tamamen bilimsel amaçlar için kullanılacağı ve katılımcıların kimliklerinin açıklanmayacağı belirtilmiştir.

\subsubsection{Verilerin Analizi}

Öncelikle araştırmacı tarafından hazırlanan sorular kartopu örneklem yöntemiyle görüşülen katılımcılar tarafından cevaplandırılmış ve görüşmede alınan bilgiler görüşme formuna not alınarak daha sonra veriler bilgisayara aktarılmıştır. Her bir görüşme ortalama 20 dakika sürmüştür. Bulgular elde edilirken katılımcıların jest ve mimikleri dikkate alınmıştır. Araştırmada öğrencilerin gizlilikleri esas alındığından dolayı veriler tablo haline getirilmiş ve çalışma deneyimi olan kadınlar K (Kadın) olarak kodlanmış ve sıralanmıştır. Daha sonra mülakat tekniği kullanılarak verilere ulaşılması planlanan bu araştırmada verilerinin çözümlenmesinde nitel araştırma tekniklerinden betimsel analiz ve içerik analizi tekniği kullanılmıştır. Veriler görüşülenden elde edildiği şekilde değiştirilmeden alıntılar şeklinde aktarılmıştır ve araştırmacı verilere göre yorumunu belirtmiştir.

\section{3. Çalışmanın Bulguları}

Çalışmanın bu bölümünde araştırmaya katılanlar hakkında tanıtıcı bilgiler ve katılımcılardan elde edilen konuya ilişkin bulgular yapılan başka çalışmalar ile karşılaştırılarak tartışılmıştır.

\subsection{1. Çalışan Kadınlar Hakkında Tanıtıcı Bilgiler}

Görüşülen on kadına dair tanıtıcı bilgiler özet olması için tablo yapılarak Tablo 1'de sunulmuştur. Kadınlara dair detaylı bilgiler verilirken etik kurallar göz önünde tutularak gerçek isimler saklı tutulmuş ve numaralandırma yapılmıştır.

Tablo1. Tanıtıcı Bilgiler

\begin{tabular}{|c|c|c|c|c|c|c|c|c|c|c|}
\hline Kişiler & Yaş & $\begin{array}{l}\text { Eğitim } \\
\text { Durumu }\end{array}$ & Meslek & $\begin{array}{l}\text { Çalıșma } \\
\text { Durumu }\end{array}$ & $\begin{array}{c}\text { Evlenme } \\
\text { Yaşı }\end{array}$ & $\begin{array}{l}\text { Evlilik } \\
\text { Süresi }\end{array}$ & $\begin{array}{c}\text { Evlilik } \\
\text { Türüi }\end{array}$ & $\begin{array}{l}\text { Eşin } \\
\text { Yaşı }\end{array}$ & $\begin{array}{c}\text { Eşin } \\
\text { Eğitim } \\
\text { Durumu }\end{array}$ & $\begin{array}{c}\text { Eşin } \\
\text { Mesleği }\end{array}$ \\
\hline K1 & 32 & $\begin{array}{l}\text { Yüksek } \\
\text { Lisans }\end{array}$ & $\begin{array}{c}\text { Sosyal } \\
\text { Hizm. Uzm. }\end{array}$ & Aktif & 27 & 5 & Severek & 37 & Doktora & $\begin{array}{c}\text { Dr. Öğr. } \\
\text { Üyesi }\end{array}$ \\
\hline K2 & 48 & Lisans & Öğretmen & Aktif & 25 & 23 & $\begin{array}{l}\text { Görücü } \\
\text { Usulü }\end{array}$ & 50 & Lisans & Mühendis \\
\hline K3 & 40 & Lisans & Hemşire & Aktif & 23 & 16 & $\begin{array}{l}\text { Görücü } \\
\text { Usulü }\end{array}$ & - & - & - \\
\hline K4 & 43 & Lise & İşletmeci & Aktif & 40 & 3 & Severek & 43 & Üniversite & İşletmeci \\
\hline K5 & 55 & Lisans & Öğretmen & Emekli & 25 & 30 & $\begin{array}{l}\text { Görücü } \\
\text { Usulü }\end{array}$ & 56 & Lisans & Öğretmen \\
\hline K6 & 43 & Lise & Aşçı & Aktif & 20 & 23 & Severek & 47 & Lise & İşçi \\
\hline K7 & 48 & İlköğretim & $\begin{array}{l}\text { Temizlik } \\
\text { Personeli }\end{array}$ & Aktif & 17 & 30 & $\begin{array}{l}\text { Görücü } \\
\text { Usulü }\end{array}$ & 52 & İlköğretim & $\begin{array}{l}\text { Serbest } \\
\text { Meslek }\end{array}$ \\
\hline K8 & 52 & İlköğretim & $\begin{array}{c}\text { Aşçı } \\
\text { Yardımcısı }\end{array}$ & Aktif & 17 & 20 & $\begin{array}{l}\text { Görücü } \\
\text { Usulü }\end{array}$ & 59 & Lise & $\begin{array}{l}\text { Serbest } \\
\text { Meslek }\end{array}$ \\
\hline K9 & 56 & $\begin{array}{l}\text { Ortaokul } \\
\text { terk }\end{array}$ & Aşçı & Aktif & 24 & 32 & $\begin{array}{l}\text { Görücü } \\
\text { Usulü }\end{array}$ & 55 & İlkokul & İşçi \\
\hline K10 & 44 & Önlisans & $\begin{array}{l}\text { Konaklama } \\
\text { İşletmecisi }\end{array}$ & Aktif & 26 & 18 & $\begin{array}{l}\text { Görücü } \\
\text { Usulü }\end{array}$ & 48 & Lisans & $\begin{array}{l}\text { Elektrik } \\
\text { Teknikeri }\end{array}$ \\
\hline
\end{tabular}

Kaynak: Yazar tarafından hazırlanmışır. 


\subsection{2. Şiddet ve Şiddet Davranışı}

Kadınlar aile içinde en fazla eş şiddetine maruz kalmaktadır. Tüm dünya nüfusunu temel alan 48 çalışmanın verilerine göre, Dünya Sağlık Örgütü (DSÖ) kadınların eşleri tarafından şiddete uğrama oranının \%10-69 arasında olduğunu belirmiştir (Krug vd., 2002:91). Çalışan kadınlar da bu oranın içine girebilmekte, ekonomik bağımsızlık kadını eş şiddetinden koruyamamaktadır.

Katılımcılara; size göre şiddet nedir? Hangi tür davranışları şiddet olarak algılarsınız sorusu yöneltilmiştir. Çalışan kadınlar, şiddeti nasıl algıladıklarını ve hangi tür davranışları şiddet olarak nitelendirdiklerini şu şekilde ifade etmiştir:

- "Fiziksel, duygusal ve ekonomik anlamda bir kişiye ya da gruba yönelik kasitlı veya kasitsız uygulanan zarar verme eylem ya da durumudur (K1)".

- "Fiziksel olarak şiddet uygulamaktır ve artı olarak sözle aşağılamak ve hakaret etmek de şiddettir (K2)".

- "Sözlü ya da fiziksel travmadır. Karşı tarafın kişiliğini, saygınlı̆̆ını olumsuz etkileyecek her türlü söz ve davranıştır (K3)”.

- "Kötü söz veya sert davranışın ya da fiziksel saldırının ortaya çıkardı̆̆ durumdur $(K 4, K 6)$ ".

- "Şiddet; fiziksel ve ruhsal anlamda bir kişiye zarar vermektir. Örnek olarak suskunluk ve astk suratl olmak gösterilebilir (K5)".

- "Şiddet bağırmak, el kaldırmak ve küfürlü konuşmaktır (K7, K8)”."

- "Şiddet erkeğin kendisini üstün görmesi, karşısındakine kaba kuvvet kullanması ve sesini yükseltmesidir (K9)".

- "Yapmak istemediğin bir şeyi zorla yapmak şiddeti tanımlar. Örneğin eşimin konuşmak istemediğim akrabalarımla beni zorla konuşturması (K10)".

Araştırmaya katılan kadınlardan çoğunluğunun şiddet denildiğinde ekonomik şiddet aklına gelmemektedir. Sadece tek bir katılımcı ekonomik şiddeti şiddet kategorisine almıştır. Görüşmelerde özellikle fiziksel ve ruhsal şiddet vurgulanmıştır.

K10, şiddetin psikolojik boyutunu ele almıştır. Her türlü baskı, tehdit ve zorlamanın olduğu davranış şiddeti meydana getirmektedir. K5 ise şiddet davranışına örnek olarak suskunluk ve asık suratlı olmayı vermiştir. K5 tarafindan konuşkan olmamak, muhabbet açmamak ve güler yüzlü olmamak şiddet olarak algılanmaktadır. Böyle kişilerle aynı ortamda bulunmanın bireye psikolojik açıdan zarar verebileceğini öngörmüştür. Yani şiddet sadece belirli bir davranışı yerine getirmek veya sadece yıkıcı eylemin ortaya çıkmasıyla oluşmamaktadır. Şiddet yapılması gereken bir davranışın yapılmaması veya ihmali neticesinde de ortaya çıkabilmektedir. Yoksunluk ve ihmalin özellikle şiddet olarak bilinmesinin öncelikli nedeni, kasıt içermesidir. Bireyler, ulaşmak istedikleri bir şeyden mahrum edilerek cezalandırılabilmektedir. Örneğin, sevgiden, şefkatten, ilgiden mahrum edilme duygusal şiddet olarak değerlendirilebilirken; kaliteli eğitim ve sosyalleşmeye engel olma kişiyi psikolojik olarak yıpratmaktadır. İhmal ise; bireyin kendisine veya sosyal çevresine yönelik olabilmektedir. İhmal ve yoksunluk art arda kişiyi bulabilmektedir. Yoksun bırakılan bireyler, yoksun bırakanları, ihmal ile cezalandırabilmektedir. Her iki durumda da sınırlandırılmış olan birey, ruhsal şiddeti bazen fiziksel şiddete dönüştürebilmektedir (Harcar vd., 2008:54).

K9, erkek egemenliğini şiddet olarak algılayarak toplumsal cinsiyet kavramına vurgu yapmıştır. Toplumsal cinsiyet farkları, toplumda önemli tabakalaşma farklarının ortaya çıkmasına neden olmaktadır. Özellikle ataerkil düşünce yapısına sahip geleneksel toplumlarda, erkek ve kadın farklı birer sosyal grup olarak kabul edilirse, erkeği kadına göre daha üstün statülü gruba yerleştirme algısı mevcuttur (Yavuz, 2016:79). Toplumsal cinsiyet kavramı kadın ve erkek olarak farklılaşan cinsiyetlerin sosyal hayatta üstlendikleri rollere bağlı olarak edindikleri bir toplumsal kabuldür. Son yıllarda toplumda cinsiyet ayrımına gidilmemesi ve tüm alanlarda eşitliğin mevcut olması sürdürülebilir refah toplumu oluşturmanın ön koşuludur (Çötok, 2015:779). 


\subsection{3. Şiddetin Kadın Üzerindeki Etkileri}

Şiddet sonucunda benlik saygısı düşen ve kendini değersiz görmeye başlayan kadında anksiyete, depresyon gibi sağlık sorunları meydana gelebilmektedir. Bu sorunlar tanılanmadığında ve tedavi edilmediğinde giderek kronikleşebilmekte, kadının yaşam kalitesi düşebilmekte, sosyal ve mesleki işlevselliği bozulabilmekte ve hatta kadınlarda intihar riski artabilmektedir.

Katılımcılara, şiddetin kadın üzerinde fiziksel, ruhsal, ekonomik etkileri var mıdır, varsa nelerdir sorusu yönlendirilmiştir. Şiddetin kadın üzerindeki fiziksel, ruhsal, ekonomik etkilerinin varlığı değerlendirildiğinde araştırmaya katılan çalışan kadınlar kendilerini şu şekilde ifade etmiştir;

"Şiddetin kadın üzerinde fiziksel, ruhsal, ekonomik etkileri elbette vardır. Fiziksel olarak vücut bütünlügünün bozulmasından başlayarak semptomatik olarak görülen disfonksiyonlar oluşabilir. Kadının ruh ve sinir sistemi dengesi bozulabilir, ekonomik açıdan sömürge haline dönüşebilir (K1)".

Ruh ve sinir dengesi bozulan, şiddete uğrayan kadınlarda psikosomatik ağrılar oluşabilmekte, şiddet bireyin mental ve biyolojik sağlı̆̆ını olumsuz yönde etkilemektedir. Kadınlar ekonomik olarak şiddete eşi tarafından maruz bırakıldığında maddi ve manevi olarak sömürülmektedir. Kapitalizmin aile içinde de uygulanabileceği görülmektedir. Çalışan kadının eşi tarafından sürekli işçi olarak görülmesi, kadına kendi parasını istediği şekilde harcama imkanı verilmemesi psikolojik şiddete de neden olabilmektedir ve bu durum aile bütünlüğünü bozabilmekte boşanma oranlarının artmasına sebebiyet verebilmektedir. Nitekim araştırma kapsamına alınan kadınların görüşleri de bu doğrultudadır. Örneğin;

"Şiddete uğrayan kadının psikolojisi bozulur, mutsuz olur, kendisini değersiz hisseder, özgüvenini kaybeder. Öncelikle kişinin kendi saygınlı̆ğn yitirmesine özgüveninin azalmasına ve sonrasında hem kendini hem de birlikte yaşadikları kişileri etkileyebilecek psikolojik sorunlara neden olur" $(K 2, K 3, K 4)$.

Katılımcılar şiddetin kadın üzerindeki psikolojik etkilerine vurgu yapmaktadır. Şiddet nedeniyle psikolojik olarak çöküş bireylerin benlik saygısının azalmasına, özgüven eksikliğine, psikiyatrik rahatsızlıklara, depresyona neden olabilmektedir. Depresyonun atlatılamaması halinde madde bağımlılı̆̆ı, intihar gibi sosyal sorunların ortaya çıkabileceği aşikardır.

"Fiziksel anlamda şiddet gören bir kadın dış görünüşü ile insanların bunu anlayacağını ve küçük düşeceğini düşünebilir. Ruhsal manada şiddet gören bir kadın ise ruh halinin karmaşıklı̆̆ nedeniyle çocuklarına olan davranışlarında sorun yaşayabilir veya iş hayatına odaklanmada (kadınin daha duygusal olması nedeniyle) zorlanma ihtimali olabilir. Ekonomik etkileri ise okuyup iş sahibi olan kadınların en temel amaçlarından biri de ekonomik özgürlügünü elde etmektir, bunun kisitlanması kadını yıpratan bir durumdur (K5)".

"Şiddetin kadın üzerinde fiziksel, ruhsal, ekonomik etkileri vardır. Fiziksel olarak etkilerine uzuv kaybl, organ kaybı örnek gösterilebilir. Şiddetin ruhsal etkisi, şiddetin bilinçaltına girerek normalleşmesi ve çocukların ebeveynlerde gördü̈̆̈̈ şiddeti aile yaşamında uygulayarak nesiller boyunca devam etmesidir. Şiddetin kişiye ekonomik etkisi ise bireyin iş motivasyonunun düşmesi ve şiddetin olduğu bir evde bereketin olmaması şeklinde açıklanabilir. Eve ne kadar para girerse girsin geçimsizlik varsa şiddet de vardır (K10)".

Şiddet konusunda yapılan çalışmalarda şiddetin kişiden kişiye etkileri farklılık göstermektedir. Yetersiz gelir nedeniyle ailenin temel ihtiyaçlarının karşılanamaması, kayıt dışı istihdam ve işsizlik gibi gelir yoksunluğu odaklı faktörlerin aile içinde kadına yönelik şiddeti tetiklediğine yönelik araştırmalar giderek artmaktadır (Aşkın ve Aşkın, 2017:20).

Katılımcıların tamamı şiddetin kadın üzerinde fiziksel, ruhsal, ekonomik etkilerinin olduğunu savunmuştur. Bulgularıma göre fiziksel şiddet, psikolojik şiddetin kaynağı olabilmektedir. Fiziksel şiddet sonrasında kadınlar evden dışarı çıkmak istemememe, yüzündeki morlukları makyajla kapatmaya çalışma, alay ve küçük düşürücü ifadelerden kaçınma davranışlarına sahip olabilmektedir. Bu durum şiddete uğrayan kadınlarda sosyal izolasyona neden olabilmektedir. Hatta şiddete uğrayan kadınlar yaftalamadan kaçınmak için şiddeti içselleştirip herhangi bir önlem almayarak öğrenilmiş çaresizlik yaşayabileceklerdir. 
Şiddete uğrayan bir kadın mutlu bir aile hayatı sürdürememektedir. Aile içi rol ve sorumluluklarını yerine getirememekte, çocuklarıyla iletişim güçlüğü yaşayabilmekte ve onlarla kaliteli zaman geçirememektedir. Maalesef ki bu durumdan huzurlu bir ortamda yaşamayı hak eden çocukları olumsuz yönde etkileyebilmektedir. Şiddete uğrayan kadının iş motivasyonu düşebilmekte ve yaptığı işte verimli olmayabilmektedir. Bu durum kariyerinde yükselmeye engel hatta iş kaybına bile neden olabilmektedir.

\subsubsection{Ekonomik Şiddet ve Ekonomik Şiddet İçeren Davranışlar}

Ekonomik şiddet; para ve ekonomik kaynakların kadın üzerinde bir kontrol, tehdit ve tahakküm aracı olarak kullanılmasıdır (Gürkan ve Coşar, 2009:125). Katılımcılardan ekonomik şiddeti ve bu şiddeti içeren davranışları tanımlanması istenildiğinde kendilerini farklı şekilde ifade etmişlerdir. Kadınlardan birisi ekonomik şiddeti; "Bir tarafin ekonomik gelire el koyması ya da harcama anlaminda kisitlanmaya gidilmesi (K1)", şeklinde tanımlarken diğeri ise; "Para harcadı̆̆ı alanlar hakkında sürekli hesap vermek, açıklama yapmak, eşinden sürekli para istemek zorunda kalmak (K2)", olarak ifade etmiştir.

Bulgularıma göre toplumdaki bazı ailelerde çalışan kadınların maaşlarını aldığında "evin reisi erkektir, evi erkek idare etmelidir" gibi düşünceyle direkt eşlerine vermekte olduklarını gözlemlenebilmektedir. Bu davranışı ataerkil toplumda yetişen kadın bazen rızasıyla gerçekleştirmektedir bazen ise erkeğin bu maaşı zorla elinden alma gibi tahakkümü görülebilmektedir.

Eşin aşırı tutumlu ve tasarruflu olması literatürde ekonomik şiddetin içerisinde yer almaktadır fakat K3'ün savurganlığı ekonomik şiddet olarak algılaması araştırmamıza farklı bir bakış açısı getirmiştir.

"Ekonomik şiddet; yaşam standartlarının maddi olarak kısıtlanmasıdır. Örneğin kadının kendi kişisel ihtiyaçları için eşin mali destek vermemesi, her ikisi de çalışlyor olsa bile bir tarafin savurgan olması, ailenin giderlerini karşılamak için destek çıkmaması (K3)".

Birlikte yaşanılan eş tarafından diğer eşe sorulmayarak gereksiz, tutarsız olarak harcama yapılması ev ekonomisini olumsuz yönde etkileyerek ekonomik şiddete neden olabilmektedir.

"Ekonomik şiddet; parasızlıktır, örneğin şahsi ve ailevi ihtiyaçları karşılayamamaktır (K4)".

Bazı durumlarda ekonomik şiddetin kaynağı sistemdeki adaletsiz gelir dağıtımından kaynaklanmaktadır. Bu durum kişisel ihtiyaçların karşılanamadığı noktaya geldiğinde yoksulluk başlamakta ve kadın bu şiddet döngüsünden olumsuz etkilenebilmektedir.

"Ekonomik şiddet; kendi kazandı ̌̆ parayı harcamada bile kendi kararını verememesidir. Íradesi dışında daha kendi parasına dokunmadan paranın eş tarafindan harcanmasıdır. Bahsettiğim gibi maaşını kendi bankadan çekmiyor olmak en uç örnektir. Para kazandı̆̆ı halde bir gömleği alırken eşine sormak veya kuaföre giderken bile eşine harcayabilir miyim diye sormak (K5)".

Aile içinde şiddetin varlığı evliliği sağlıklı bir şekilde yürütmeye engel olabilmektedir. Çağımızın güncel sorunu olan boşanma git gide artmaktadır. Bu noktada K6 ekonomik şiddet sonucunda kadınların boşanma talebinde bulunabileceğini ifade etmiştir. "Ekonomik şiddet kadını boşanmaya iten içsel bir tükeniştir (K6)". Boşanma oranlarının azalması için ekonomik şiddetin önlenmesi önem teşkil etmektedir.

"Kadını çalıştırmamak ve kadını parasız bırakmak ekonomik şiddettir (K9)". Litaratürde kadının zoraki çalıştırılması da şiddet, kadının istediği halde çalıştırılmaması da şiddet olarak yer almaktadır. Burada önemli olan kadının hür iradesiyle çalışma yaşamına katılıp katılmayacağına karar vermesidir.

"Ekonomik şiddet, ekonomik bağımsızlığının engellenmesidir. Eşinden habersiz dışarıda bir bardak çay bile içememek ekonomik şiddete en güzel örnektir. Çalışmadiğım zamanlarda eşim kredi kartını bana vermişti ama ben parayı kazanmadığımı düşünerek kredi kartımı kullanamiyordum (K10)".

Ekonomik şiddet, kadınların karşılaştığı şiddet tiplerinden en etkilisidir. Çünkü ekonomik şiddet; kişilerin psikolojik ve fizyolojik sağlığını olumsuz etkileyen koşullara karşı çıkma gücü, ekonomik bağımsızlıkla doğrudan ilişkilidir. Ekonomik bağımlılık kadının diğer şiddet türlerini yaşama hususunda en fazla dezavantaj oluşturan faktör olmaktadır (Eşkinat 2013:292).

Türkiye'de Kadına Yönelik Aile İçi Şiddet Araştırması, T. C. Başbakanlık Kadının Statüsü Genel Müdürlüğü tarafından yapılan 2014 yılı araştırma sonuçlarına göre; Türkiye genelinde ekonomik şiddet davranışlarından en az birine yaşamın herhangi bir döneminde maruz bırakılan kadınların oranının \%30, son 12 ayda maruz kalan kadınların oranının ise \%15 olduğu belirtilmiştir. Çalışmaya engel olmanın ya da bir işten ayrılmaya neden 
olmanın kadınların en yoğun olarak maruz kaldığı ekonomik şiddet biçimi olduğu belirtilmiştir. Yaşamın herhangi bir döneminde kadınların dörtte birinin, son 12 ayda ise kadınların onda birinin bu istismara maruz kaldığ ifade edilmiştir. Kadınların yaşamlarının herhangi bir döneminde, ev ihtiyaçları için para verilmemesinin kadınların \%9'unun maruz kaldığı bir davranış olduğu belirtilmiş̦tir. Evlenmiş kadınların gelirinin elinden alınması ise, $\% 5$ düzeyinde karşılaşılan şiddet türü olarak belirtilmiştir.

Katılımcılar kendi açılarından ekonomik şiddeti ve bu şiddeti içeren davranışları değerlendirmişlerdir. Çalışan veya çalışmayan kadınlarda aile gelirini harcarken kadının bazı kişisel ihtiyaçlarının giderilmesi sürekli olarak ertelenebilmektedir. Öncelik diğer masraflara verilebilmekte ve bu durum neticesinde kadın kendini değersiz hissedebilmektedir. Kadın mutsuz olduğunda bu durum diğer aile bireylerine aksettirilerek aile içi huzursuzluk meydana gelebilmektedir.

\subsubsection{Ekonomik Şiddet Uygulayan Eşin Varlığı}

Kadınlar eşlerinin kendilerine ekonomik şiddet uygulayıp uygulama durumlarını;

- "Bir miktar uyguluyor diyebilirim. Almak istediklerim hakkında sik sik buna gerek yok diyerek ekonomik şiddet uyguluyor (K2)".

- "Hayır uygulamiyor $(K 3, K 6, K 7, K 8)$ ".

- "Eşim uygulamiyor ama hayat pahalılığ buna sebep oluyor (K4)".

- "Uyguluyor. Aslında bir önceki soruda verdiğim örnekler kendi üzerimden verdiğim örneklerdir. Belki 20 yıl boyunca maaşımı eşim bankadan çekti ve harcama konusunda aslında birlikte aldı̆̆ımız kararlar neticesinde olan borçlar ödense bile maaşımın hiç elime geçmiyor oluşu özellikle emekliliğe yakın süreçte büyük kavgalara neden oldu. Şu anda emekli ikramiyemi harcama konusunda kendim karar veriyorum ve artık emekli maaşımı kendim kullanıyorum (K5)".

- "Geçmişte ekonomik şiddete maruz kaldım. Illk işe başladığımda eşim benimle bir hafta konuşmadl. Bunun nedenini sorguladığımda eşimin ailesinde ve akrabalarında çalışan kadının var olmamaslydı. Gelin olarak çalışan ilk kadın bendim, eşimin bu duruma alışması biraz zaman ald $($ (K6)".

- "Eşim ekonomik şiddet uyguluyor. Parayı kendisi istediği gibi harcar ama ben harcama yapınca çok para harclyorsun diyor. Bu söylemi alı̧̧kanlık haline geldi (K9)”.'

- "Eşim ekonomik şiddet uygulamiyor fakat israfa kaçmamam ve tasarruf etmem için beni uyarlyor (K10)".

Katılımcıların çoğunluğu eşi tarafından ekonomik şiddete maruz kalmadığını belirtmiştir. "K4" ise ekonomik şiddete uğradığını fakat bunun eşi tarafından gerçekleştirilmediğini, elde edilen gelirin ihtiyaçları karşılamaya yetmediğini belirterek yaşamlarında ekonomik şiddetin varlığından söz etmiştir.

"K5" çalışma hayatı boyunca eşinden ekonomik şiddet görmüştür. Emeklilik onu bir anlamda ekonomik özgürlüğüne kavuşturmuştur fakat yılların getirdiği sorunların birikimiyle evlilikte büyük krizler meydana gelmiştir. Çalışma hayatı boyunca maaşını kullanabilme seçeneği sunulmayan kadın kendisini sürekli kocasına bağımlı olarak hissetmiş̧ir.

Gürkan ve Coşar'a göre (2009:125), toplumun sosyal ve kültürel yapıs1, dini inançlar, sosyal izolasyon, toplumsal roller, yoksulluk, cinsiyet eşitsizliği, özdenetim yetersizliği ve karakter zayıflığı gibi özel ölçütler ekonomik şiddet riskini artırmaktadır. K6'nın eşi, toplumsal geleneklere bağlı kalarak eşinin çalışmamasını ve ev içi rol-sorumluluklarını yerine getirmesini beklemiştir. Fakat kadının ev içinde gerçekleştirdiği iktisadi faaliyetler, piyasa dışı faaliyet olarak kabul edilmektedir. Piyasa dışı olarak kabul edilen ev içi işler çoğu zaman ücrete tabi olmadan yapılmaktadır. Kadın zihinsel ve fiziksel olarak emek sarf etmeyi gerektiren bu işler karşılığında herhangi bir gelir elde edememektedir. Kadının ev içi üretimi sosyal ilişkilerin ona yüklediği bir rol olmasına rağmen, yapılan ev işleri kadın olmanın bir doğal sonucu olarak görülmekte ve bu durumda kadının emeğini görünmez kılmaktadır. Dolayısıyla bu durum, kadının emeğinin ikincil ve önemsiz emek olmasına yol açmaktadır (Korkmaz ve Korkut 2012:53). 


\subsubsection{Eşin Kadının Çalışmasına Bakışı}

Çalışmadan hoşlanma ve ekonomik bağımsızlık kadınların çoğunu çalışma hayatına yönelmeye motive eden en önemli faktörler olduğu yapılan bir çalışmada belirtilmiştir (Tatlı ve Koç, 2017:152). Ülkemizde yapılan çeşitli araştırmalarda genel olarak kadınların çalışma hayatına atılmasına olumlu yaklaşıldığı ifade edilmiştir. İstisna olarak kadınları çalıştırmak istemeyen eş, baba, kardeş modeli mevcuttur (Kuzgun ve Sevim, 2004:17).

Kadınlar üzerinde 2011 senesinde Özçatal'ın yaptığı araştırmada kadınların \%52,7'si erkeğin eşinin çalışmasına müsade etmesi gerektiğini, \%37,9’u ise zorunluluk halinde müsade etmesi gerektiğini ifade etmiştir. Anlaşıldığ1 gibi kadınların yarısından fazlası çalışma yaşamını kabullenmiş olmasına rağmen kocanın çalışmaya müsade etmemesi durumunda çalışmayacağını ifade etmektedir. Kadının işgücüne katılımı ile erkek denetimi arasındaki içselleştirilmiş bir ilişki meydana gelmektedir. Eşin, kadının sosyal hayatta çalışmaya bakış açısı kadının çalışma tercihini belirlemesinde etkili olmaktadır. Çalışan kadınlar eşlerinin, çalışmalarına nasıl baktığını şu şekilde ifade etmişlerdir:

- "Çalışma konusunda beni serbest birakıyor, kendim isteyerek çalışıyorum (K1,K2, K8)".

- "Eşim çalışmama iyi gözle bakıyor, beraber çalışlyoruz (K4)”.

- "Eşim çalışmama şu anda çok saygllı ama önceden çok çektim. İlk çalışı̆̆ı̆m zamanlar çalışmama olumsuz baklyordu (K6)”.

- "Hayat şartları zor ve pahalı olduğu için eşim çalışmama iyi gözle baklyor. Tek maaşla geçinemiyoruz $(K 7, K 9)$ ".

- "Eşim bir başkasının emrinde çalı̧̧mama olumsuz bakıyor. Çalışacaksan kendi işin olsun diyor ve ben onun desteğiyle iş kurdum. Ev hanımlı̆̆ının sultanlık olduğu görüşünde eşim. Kadın dışarıda çalıştı̆̆ında Türk aile yapısının bozulduğu kanaatinde (K10)”.

Katılımcıların hepsinin eşi hayat arkadaşlarının çalışmasına olumlu yaklaşmaktadır. Bu yaklaşım ve çalışıp çalışmama konusunda serbest bırakmak ekonomik şiddeti önleme noktasında önemli bir adım olarak görülebilmektedir.

TÜIK'in "Kadına Yönelik Aile İçi Şiddet" araştırmasının sonuçları incelendiğinde, aile içinde refah düzeyi arttıkça aile içi şiddete maruz kalma olasılığının düştüğü görülmüştür. Düşük refah düzeyine sahip kadınların $\% 47$ 'si, orta refah düzeyine sahip kadınların $\% 38,9$ 'u ve yüksek refah düzeyine sahip kadınların ise \%26,7'si fiziksel şiddete maruz kalmıştır (TÜIK, 2018). Bu durumda kadınlar aktif işgücüne katılırsa ailenin refah düzeyi artacak ve şiddet azalacaktır. Hane içine daha fazla para girme olasılığı eşlerin, kadınların çalışmasına bakış açısını olumlu etkilemektedir. Nitekim K7 ve K9'un görüşleri bu durumu desteklemektedir.

Antalya'da yapılmış olan bir araştırmada 15-49 yaş aralığında olan kadınların \%75.7'sinin çalışmadığı; bu kadınların \%89.3'ünün ev hanımı olduğu, \%2.5'inin küçük yaşta çocuğa sahip olduğu, \%4.5'inin ise eşinin izin vermemesi nedeniyle çalışmadığı bulgularına ulaşılmıştır (Kılıç, 2014:217). Diğer bir araştırmada ise katılımcılara kadının konumu ile ilgili sorular yöneltilmiş ve evli erkeklerin \%64,3'ünün kadınların vazifesinin annelik, \%22'si ise ev işlerini yapmak ve kocasına bakmak olarak gördüğü kaydedilmiştir. Kadını, "eşinin hayat arkadaşı" gibi daha eşitlikçi olarak ifade edenlerin oranı ise \%13,8 olarak bulunmuştur (Ökten, 2009:308). K10'un eşi ise kadının önceliğinin ev hayatı olduğu ve ev hanımlığınının statüsünü yüksek görerek daha önce yapılan çalışmaları destekler nitelikte görüş sunmuştur.

\subsubsection{Ev İşlerine Olan Katkısından Dolayı Kadınların Takdir Edilmesi}

Evdeki iş sorumluğunun tamamıyla kadının üzerinde olması kadının çalışma hayatında ve kariyerinde ilerleme isteğini olumsuz etkilemektedir. Hala sosyal hayatta devam eden "kadının yerinin evi olduğu" algısı kadının işgücüne katılmasına ve mesleğinde ilerlemesine engel olabilmektedir (Kazgan, 1979'dan akt.: Kuzgun ve Sevim, 2004:17).

Çalışan kadınlara ev işlerine katkınızdan dolayı eşiniz sizi takdir ediyor mu sorusu yöneltilmiştir. Katılımcılardan bazıları;

"Takdir ettiğini sözlü olarak yeterince ifade etmiyor (K2,K6,K7,K8,K9,K10)",

diğerleri ise;

"Evet, beni takdir ediyor (K4)", 
"Eşim ev işlerine olan katkım nedeniyle beni takdir etmiyor. Daha çok onun bana ev işlerine yardım ettiği için ben teşekkür ediyorum (K5)",

şeklinde sorumuza yanıt vermiştir. Katılımcılarının genel ifadelerine göre erkekler kadınların evdeki çalışmalarının farkında olup onları bu konuda takdir etmektedir. "K2", eşinin bu ifadeyi daha sık dile getirmesini istediğini belirtmiştir. Kadının evde yaptığı iş bazı erkekler tarafından küçümsenebilmekte ve önem verilmemektedir. Ancak düzenli olarak ev işi yapan kadının bu düzeni aksattığında erkekler kadınların sürekli çalıştığını algılayabilmektedir. Eşler ortak yaşadıkları evde ortak sorumluluk alabilmeli, ev işleri sadece kadının üzerine yüklenmemelidir. Eşler birbirlerini bu noktada teşvik etmeli ve birbirlerine teşekkür etmelidirler.

Evlilikte erkek ve kadının sorumlulukların farkında olması eşler arasında görevlerin dengeli bir şekilde paylaşılması yönüyle önem arz etmektedir. Toplumsal cinsiyet rollerine bakıldığında evlilikte kadının "içeriden" yani ev ve aileyle ilgili işlerden sorumlu olduğu; erkeğin ise "dışarıdan" yani iş, geçim gibi konulardan sorumlu olduğu anlaşılmaktadır (Gülpınar ve Kandemirci, 2013:31). Bu anlayış bireylere sorumluluk alanlarına dair sınırlar çizmekte ve vazifelerin yerine getirilmesi halinde refaha ulaşılacağı düşüncesini savunmaktadır. Fakat toplumsal cinsiyet rollerine dair sınırın bu derece keskin çizilmesi, kadının sorumluluk alanı olarak görülen ev ortamında erkeğin görev almamasına ve kadının da ev dışında yeterince sosyalleşememesine neden olabilmektedir. Aile ortamında kadının sahip olduğu birçok rolle beraber kadının ev içi emeğinin değersiz görülmesi nedeniyle ruhsal, ekonomik, fiziksel, cinsel gibi birçok şiddet türüyle karşılaşması günümüzde sık karşılaşılan sorunlardandır (Genç vd., 2019:395).

\subsection{8. Çalışan Kadının Maaş Kartı Kullanımı}

Geleneklerine bağlı toplumlarda süregelen ataerkil aile içi ilişkiler ve toplumsal cinsiyet temelli iş bölümü, kadın belirli bir para karşılığında çalışsa da parasını harcamada yeterince özgür olamamaktadır. Kazanılan paranın erkeğe teslimi, ailede erkeğin kararlarının hakim olduğu bir aile yaşantısını meydana getirmekte ve erkek üstünlüğünü pekiştirmektedir (Özçatal, 2011:25). Diğer taraftan kadınların çalışma hayatına ilişkin görüşleri konusunda yapılan bir çalışmada, çalışma hayatının kadına ekonomik bağımsızlık ve sosyalleşme imkânı sağladığı ve kadının öz güvenini de arttırdığı konusunda eğitim düzeyi ile bu görüş arasında anlamlı bir ilişki olduğu bulunmuştur (Ersoy ve Ersoy, 2018:347).

Çalışan kadınlara ekonomik şiddetin uygulanıp uygulanmadığını ölçmek amacıyla maaş kartınızı eşiniz kullanıyor mu diye soru sorulmuştur. Kullanıyor ise bunun sebepleri irdelenmek istenmiştir. Çalışan kadınlar bu konuda kendilerini şu şekilde ifade ettiler:

- "Maaş kartımı eşim kullanmıyor, sadece ben kullanıyorum (K1)".

- "Büyük miktarda borçlandığımız için 6 yıldır maaşs kartımı eşim kullanıyor. Önceden kartımı ben kullaniyordum (K2)”.

Evlilikte ortak amacı gerçekleştirmek düşüncesiyle maaş kartının eşe verilebildiği ortaya çıkmıştır. Örneğin müşterek ev almak için borçlanmak gibi.

"Eşim kullanıyor. Gelir, gider ortak kabul edildiği için bir de birliktelik açısından kullanmasına izin veriyorum $(K 3, K 6, K 7)$ ".

Ailede ekonomik gelirin harcanmasına yönelik ülkemizde yapılan bir çalışmada kadınların \%38'i kendisi, \%50'si kocası veya diğer kişilerle beraber karar verirken, \%10'unun kararda etkisinin olmadığı saptanmıştır. Ekonomik gelirin harcanmasına karar verme, yaşı daha büyük kadınlarda yüksek iken, 15-19 yaş arasındaki kadınların \%26'sının kendi maaşının tasarrufunda söz hakkının olmadığı belirtilmiştir (TNSA ${ }^{1}, 2004: 39$ ). Bu durum çalışan kadınların bir kısmının maaş kartını eşine verdiğinin bir göstergesidir. Kadının kendi parasını kullanma iradesinin elinden alınmasıyla kadın erkeğin iş̧̧isi konumuna düşebilmektedir. Bu durum evliliğin ortaklaşma yapısıyla çelişebilmekte ve bencil bireylerin sayısını arttırabilmektedir.

- "Maaş kartımızı eşimle ortak kullanıyoruz (K4,K10)".

- "Maaş kartımı eşim kullanıyor. Aslında evliliğimizin başlarında böyle başladı ve devam etti (K5)".

- "Maaş kartımı eşim kullanmıyor, sadece ben kullanıyorum (K8)".

1 Hacettepe Üniversitesi Nüfus Etütleri Enstitüsü tarafindan hazırlanan bu rapordan sonra yine aynı enstitü tarafindan 2008 , 2013 ve 2018 yıllarında da Türkiye Nüfus ve Sağlık Araştırması Raporları hazırlanmıştır. Ancak sonraki raporlarda karar alma ile ilgili inceleme yapılmadığı tespit edilmiş̧tir. Bu nedenle verinin zamansal seyri değerlendirilememiştir. 
"K5", evliliğin ilk başlarında eşinin maaş kartını almasına ses çıkaramamış daha sonra bu durum alışkanlık haline gelerek devam etmiştir. "K5", yıllardır bu durumu içselleştirerek hayatına devam etmiştir. Ekonomik şiddete aile yaşamının sağlıklı bir şekilde devam etmesi için göz yuman "K5" yıllardır bu baskıyı psikolojik ve ekonomik olarak yaşamıştır. K8 ise maaş kartını sadece kendisinin kullandığını ifade etmiştir.

Bir araştırmaya göre katılımcı olan kadınların sadece beşte birinin gelir getiren bir işte çalıştığı, çalışan kadınların bir kısmının maaş kartlarının eşlerinin denetiminde olduğu ve ziynet eşyası olan kadınların büyük çoğunluğunun ziynet eşyası kontrolünü eşlerinin sağladığı belirlenmiştir (Yılmaz ve Öz, 2017:100). Toplumumuzda maaş kartının kontrolü eşinde olan kadınlar ekonomik şiddeti derinden yaşayabilmekte ve bu durumu yakın çevresiyle paylaşamamaktadırlar.

\subsubsection{Ekonomik Şiddetin Önlenmesi}

Çalışan kadınlara yapılan ekonomik şiddet çok ciddi kayıplara neden olabilmektedir. Kadınların bu konudaki farkındalıkları arttırılarak gerekli önlemlerin alınmasında sosyal hizmet uzmanlarına önemli görevler düşmektedir. Ekonomik alanda yapılan şiddetin yoğunluğu ise kişinin ekonomiye olan katkısının değersizleştirilmesi, ekonomik alanda varlığını sürdürememesi sonucunu doğurmaktadır (Yavaş ve Ersoy, 2016:8).

Katılımc1lara "sizce ekonomik şiddet önlenebilir mi?" ve "Nasıl önlenebilir?" sorular1 yöneltilmiştir. Kat1lımc1lar; "Önlenmesini zor görüyorum. Ülkede ekonomik durumun iyileşmesi ve kişilerin zihinsel gelişimi ile doğru orantıl olarak şiddet önlenebilir (K2)”, diyerek K2 ekonomik şiddetin önlenemeyeceğini, K4 ise "Önlenebilir ama bunu yapabilecek kişiler devlet büyükleri (K4)", diyerek önlenebileceğini savunmuştur.

Kadına yönelik ekonomik şiddetin önlenmesi ile ülkemizdeki refah seviyesi arasında bağlantı kurulmuştur. Bir ülkede ekonomik kalkınmanın gerçekleşmesi, adil gelir dağılımın uygulanması, işsizliğin asgari düzeye düzeye indirilmesi ekonomik şiddetin de azalmasına neden olabilecektir. Aile içinde yaşanan ekonomik buhran şiddetin kaynağını oluşturabilmektedir. Ekonomik buhranın asıl nedeni ise sistem yetersizliğinden kaynaklanabilmektedir. Ortak kararların alındığı bir aile hayatında ekonomik şiddetin önlenebileceği sonucuna varılmıştır.

\section{"Önlenebilir, iki tarafin ortak geliri üzerinde söz sahibi olarak ortak kararla hareket etmesi gerekiyor (K1)".}

Erbil ve Pasinlioğlu'nun 2001 senesinde yaptığı çalışma neticesinde; ailede eşlerin birlikte karar verme oranının ortalama \%42.8 olduğu, eşlerin tek başına karar verme oranlarının ise kadınlarda ortalama \%27.3, erkeklerde $\% 22$ olduğu saptanmıştır. Bununla beraber; erkek ve kadınların ailede tek başına karar verdikleri konular incelendiğinde, daha önem arz eden konularda erkeklerin, daha az önem arz eden konularda kadınların karar verdiği belirtilmiştir. Eğitim düzeyi yüksek ve genç olan kadınların ailede karar vermede daha etkili olduğu, eğitim açısından gelişme olmasına rağmen, geleneksel aile düzenine ait davranış ve turtumların devam ettiği görülmüştür (Erbil ve Pasinlioğlu, 2004:10-11). Bu çalışmaya göre eşler genellikle ortak karar alarak evliliğini sürdürmektedir. Bulgularıma göre evlilikte ortak kararların uygulanması ekonomik şiddeti önlemek için bir etken olabilmektedir.

“Tabii ki önlenebilir diye düşünüyorum. Erkeğin hakim olduğu bir toplum yapımız var, kadınların da özgür olabildiğinin ve bă̆ımsız olduklarının eğitimini öncelikle çocuklarımıza ve özellikle de erkek çocuklarımıza ögreterek önleyebiliriz. Kavga ederek, tartışarak değil de bu parayı kazanıyorsa bir kadın bunu harcama konusunda özgürlügü olduğuna ikna etmeliyiz (K5)”.

“Özellikle kız çocuklarımızı bu konuda bilinçlendirirsek, onların ekonomik özgürlüğ̈̈nü eline alması için gereken desteği verirsek ekonomik şiddeti önleyebiliriz. Öncelikle bazı zihniyetler (ataerkillik gibi) değişirse böyle sorunların olmayacă̆ını düşünüyorum (K6)”.

“Ekonomik şiddet önlenemez çünkü bu bir yapıyla karakterle ilgili bir durumdur. Ekonomik basklşiddet gösteren insanlar tükenmez (K8)”.

"Kadın çalışsa da çalışmasa da ekonomik şiddet önlenemez. Sadece ailede ekonomik şiddetin var oluş biçimi değişir. Kadın çalışsa kendi param diyip ev ekonomisine katkıda bulunmak istemeyebilir veya kadın eşinden yüksek statüde çalışıyorsa erkek bu durumdan rahatsı olup huzursuzluk oluşturabilir. Kadın çalıştığında çocuklarıyle ve eşiyle yeterince ilgilenmediği takdirde de ailede şiddet meydana gelebilir (K10)". 
Bir araştırmada kadının çalışma yaşamında yer almasının şiddeti engellemediği ortaya konmuştur. Özellikle fiziksel şiddet gördüğünü ifade eden katılımcıların 5'i çalışma yaşamında yer almazken, 6 katılımcı işgücünde aktif rol almakta ve ekonomik gelir elde etmektedir. Şiddet gören katılımcıların yardım almaktan kaçındıkları görülmektedir. Çocukların varlığı ve yardımın kesin bir çözüm olmayacağı düşücesi yardım almayı engelleyen iki temelfaktördür. Yardım alma ihtiyacı ve bunu gerçekleştirme durumu ancak boşanmayı düşünenler tarafından gerçekleştirilebilmeltedir (Akıncı Çötok, 2015:787-788). Kadınların işgücünde aktif katılımının olması, ekonomik özgürlüğün olması ve maddi gelir elde ediyor olması aile içindeki şiddeti engelleyemeyebilir, bazı zamanlarda bu durum şiddeti tetikleyebilir.

Katılımcıların genel olarak ekonomik şiddetin önlenebileceğine dair umudu vardır. Özellikle erkek çocuklarının yetiştirilirken cinsiyetçi, erkek üstünlügü gibi yaklaşımlardan kaçınarak daha demokratik, özgürlükçü, eşitliği ve adaleti savunucu bir yaklaşımın benimsenmesi gerekmektedir. Toplumsal bilincin bu yönde gelişmesi için çocuklarımızın şiddet görülmeyen evlerde büyümesi gerekmektedir. Çünkü şiddet bir nevi öğrenilmiş bir davranış olabilmektedir. Ebeveynler ekonomik şiddet uygulamayarak geleceğin ebeveyni olacak çocuklarına örnek olmalıdır.

Şiddet Önleme ve İzleme Merkezleri (ŞÖNIM) şiddeti önleme adına kurulan işlevsel devlet birimleridir. Şiddet ŞÖNIM , 2012 yılın Aralık ayından itibaren 14 ilde pilot uygulama ile hizmet vermeye başlamıştır. Yapılan iki yıllık pilot uygulama ile birlikte şiddet mağdurlarına hızlı ve sistemli hizmet vermeyi amaçlayan bu merkezler daha sonra tüm illerde uygulamaya geçecek şekilde hizmet vermeye başlamışlardır. Kadın erkek eşitliğini savunan ve kadınların kendilerini güçlendirmeye yönelik çalışmaların yapılması konusunda kadın refahını arttırmaya yönelik hizmet eden bir kuruluştur, gizlilik ilkesini de esas alır (Altıparmak, 2018:388-399). Bursa ŞÖNIM'e başvuruda bulanan kadınların \%70'ten fazlasının ekonomik gücü yoktur. Kadının şiddet uygulayan eşe ekonomik açıdan bağımlı olması şiddet ortamından kurtulma yönünde cesaret kırıcı bir etki oluşturmaktadır. Kadının ekonomik özgürlüğünün olmaması şiddetin devamını sağlayan ve katlanılması zorunlu bir hale dönüştüren bir etki haline gelmektedir (Yanık vd., 2014:109).

\section{SONUÇ VE ÖNERILER}

Kadına yönelik şiddet kavramı, güncelliğini sürdüren, evrenselleşen bir olgu haline gelmiştir. Ülkemizde ve dünyada şiddetin görülme sıklığı her geçen gün artabilmektedir. Kadına yönelik şiddetin temelinde toplumsal cinsiyet eşitsizliği yer alsa da sosyal ve kültürel etkenler de şiddete sebep olabilmektedir.Çalışan kadınlar, eşleri tarafından ekonomik şiddete uğrayabilmektedir. Bulgulara göre çalışan kadınlar şiddet kavramını özellikle fiziksel ve ruhsal şiddet olarak algılamaktadır. Ekonomik şiddet kavramı diğer şiddet türlerine göre fazla bilinmemektedir.

Çalışan kadınlar ekonomik bağımsızlığı olsa da erkeğin baskısı altında ezilerek kendi parasını dilediğince harcayamamaktadır. Maaş kartı kullanımı erkeğin eline geçebilmekte ve kadın sürekli işçi pozisyonuna girebilmektedir. Bu durum sonucunda kendini gerçekleştirememiş, özgüveni olmayan, pasif kadınlar var olabilmektedir. Ekonomik şiddet sonucunda psiko-sosyal dengesi bozulan kadın sosyal çevresiyle kaliteli zaman geçirememekte sağlıklı iletişim kuramamaktadır. Ekonomik şiddet sadece belirli bir davranışı yerine getirmekle değil sosyal ve ekonomik ihtiyaçların ihmali neticesinde de ortaya çıkabilmektedir. Aile içi iletişimsizlikle birlikte kadının maddi ve ruhsal ihtiyaçlarının göz ardı edilmesi ekonomik şiddeti desteklemektedir. Ekonomik şiddet; kadınların fiziksel ve ruhsal sağliklarını olumsuz yönde etkileyebilmektedir. Çalışan kadınlarda ekonomik şiddete bağlı olarak psikosomatik ağnılar oluşabilmektedir. Aynı zamanda ekonomik şiddet, bireyin yalnızlaşmasına, sosyal izolasyona neden olabilmekte ve bu sebeple etkileşimin zayıf olduğu toplumlar artabilmektedir.

Ekonomik şiddetin temel kaynağı sistem yetersizliğinin varlığıdır. Ülkedeki gelir dağılımının adaletsiz olması sonucunda yoksulluk oluşmakta ve yoksulluk sonucunda ise ekonomik şiddet arttırabilmektedir. Çalışan kadının eş tarafından yaşadığ ekonomik şiddet nedeniyle iş motivasyonu azalabilmekte, yaptığ işte başarılı olamamaktadır. $\mathrm{Bu}$ durum ülke kalkınmasını olumsuz yönde etkileyebilmektedir. Ekonomik şiddet, toplumumuzun ortaya çıkmayan yarasıdır. Birçok kadın yaşadığı ekonomik şiddetin ya farkında olmamakta ya da farkında olsa bile bu davranışı içselleştirerek kimseyle paylaşamamaktadır. Bu konuyla ilgili ülkemizde farkındalığı arttırmak amacıyla çalışmalar yapılmalı, ekonomik şiddet danışma birimleri kurulmalı ve bu birimlere sosyal hizmet uzmanları istihdam edilmelidir. Şiddetle mücadelede multi-disipliner çalışma önem arz etmektedir. Halk sağlığı çalışanları, sosyal hizmet çalışanları ve adalet bakanlığı bünyesindekiçalışanlar arasındaki işbirliği ve uyum başta ekonomik şiddet olmak üzere diğer şiddet türlerine yapısal çözüm arayışları bulmada faydalı olacaktır. 
Şiddetin meşru görülmesi, normalleştirilmesi sosyal refahın azalmasına sebebiyet verebilmektedir. Öncelikle şiddetin kabul edilebilir algısı değiştirilmeli ve mağdurların gerekli mercielere ulaşmaları için teşvik edici çalışmalar yapılmalıdır.

Kadının haklarını koruyacak, kadın-erkek istihdam eşitliği sağlayacak sosyal politikalara ihtiyacımız vardır. Gerek sivil toplum kuruluşları gerekse devlet şiddetle mücadelede seferber olmalıdır. Şiddetin aile ve toplum hayatından arındırılmasında eğitimin önemi büyüktür. Cinsiyet ayırt etmeden bireylere çocukluklarından itibaren her türlü şiddete başvurmalarını engelleyecek eğitim programlarına ihtiyaç vardır. Bu tür programlar zenginleştirilerek yaygınlaştırılmalıdır.

\section{KAYNAKÇA}

AKINCI ÇÖTOK, Nesrin (2015), “Toplumsal Cinsiyet Rolü Dâhilinde Kadına Şiddet Olgusuna Karşı Kadın Algisl”, International Journal of Social Sciences and Education Research, S.1(3), ss.778-790.

ALTIPARMAK, İpek Beyza (2018), "Şiddete Maruz Kalan ya da Barınma Sikıntısı Yaşayan Kadınların Sosyal ve Ekonomik Değişkenler Açısından İncelenmesi”, Mehmet Akif Ersoy Üniversitesi İktisadi ve İdari Bilimler Fakültesi Dergisi, S.5(2), ss.383-396.

ATAKLI YAVUZ, Rüya (2016), "Toplumsal Cinsiyet Eşitsizliği Ekseninde Kadin İstihdami ve Ekonomik Şiddet”, Journal of Life Economics, S.3(3), ss.77-100.

ATMAN, Ümit Can (2003), "Kadına Yönelik Şiddet; Cinsel Taciz / Irza Geçme”, Sürekli Tıp Eğitim Dergisi, S.12(9), ss.333-335.

AŞKIN, Elif Özlem ve AŞKIN, Umur (2017), "Kadına Yönelik Aile Iç̧i Şiddet ve Yoksulluk İlişkisi: Aile İçi Şiddet Mă̆duru Kadınlar Üzerine Bir Araştırma", Kapadokya Akademik Bakış Cappadocia Academic Review, S.1(2), ss.16-37.

BİLGIN ŞAHIN, Berna ve ERBAY DÜNDAR, Pınar (2017), "Kadına Yönelik Şiddet ve Yaşam Kalitesi", Anadolu Psikiyatri Dergisi, S.18(3), ss.203-210.

BİLİCAN GÖKKAYA, Veda (2009), "Türkiye'de Şiddetin Kadın Să̆lığına Etkileri", Cumhuriyet Üniversitesi İktisadi ve İdari Bilimler Dergisi, S.10(2), ss.167-179.

BİLICAN GÖKKAYA, Veda (2011), "Kadına Yönelik Ekonomik Şiddet: Sivas İli (Cumhuriyet Üniversitesi) Örneği", Zeitschrift für die Welt der Türken Journal of World of Turks, S.3(3), ss.129-145.

BİLİCAN GÖKKAYA, Veda (2011), "Türkiye'de Kadına Yönelik Ekonomik Şiddet", Cumhuriyet Üniversitesi İktisadi ve İdari Bilimler Dergisi, S.12(2), ss.101-112.

BİLICAN GÖKKAYA, Veda (2014), "Cam Tavan, Kadın ve Ekonomik Şiddet", International Journal of Social Science, S.2(26), ss.371-383.

BONOMI, Amy E., THOMPSON, Robert Smith, ANDERSON, Melissa, RAID, Robert J., CARRELL, David, DIMER, Jane Ann, RIVARA, Frederick P. (2006), "Intimate Partner Violence and Women's Physical, Mental and Social Functioning", American Journal of Preventive Medicine, S.30(6), ss.458-466.

CAN GÜRKAN, Özlem ve COŞAR, Fatma (2009), "Ekonomik Şiddetin Kadın Yaşamındaki Etkileri", Maltepe Üniversitesi Hemşirelik Bilim ve Sanatı Dergisi, S.2(3), ss.124-129.

ÇALIŞKAN, Hande ve ÇEVIK, Emrah İsmail (2018), "Kadına Yönelik Şiddetin Belirleyicileri: Türkiye Örneği”, Balkan Sosyal Bilimler Dergisi, S.7(14), ss.218-233.

ÇEPNI, Salih (2010), Araştırma ve Proje Çalışmalarına Giriş, (Yazarın Kendi Yayını), Trabzon, 5. Baskı.

DEMIRER, Temel (2007), “Kadın Sorunundan Kareler”, Küreselleşme, Kadın ve Yeni Ataerki (Ed. Sibel Özbudun, Cahide Sarı, Temel Demirer), Ütopya Yayınları, Ankara, ss.1-227.

DILLON, Gina; HUSSAIN, Rafat; LOXTON, Deborah; RAHMAN, Saifur (2013), "Mental and Physical Health and Intimate Partner Violence against Women: A Review of the Literature", International Journal of Family Medicine, ss.1-15.

DİNDAŞ, Hamide (2008), "Kadina Yönelik Eş Şiddetinin Sosyoekonomik Durum ve Yaşam Kalitesi ile İlişkisi", Yüksek Lisans Tezi, Selçuk Üniversitesi Sağlik Bilimleri Enstitüsü, Konya. 
ERBİL, Nilüfer ve PASINLİOĞLU, Türkan (2004), "Kadının Ailede Karar Vermeye Etkisi", Atatürk Üniversitesi Hemşirelik Yüksekokulu Dergisi, S.7(2), ss.1-11.

ERSOY, Ali Fuat ve ERSOY, Yasemin (2018), "Kadınların Çalışma Hayatına Illişkin Görüşleri", 2.Uluslararası Türk Dünyası Eğitim Bilimleri ve Sosyal Bilimler Kongresi Bildiriler Kitabı, S.2(5), ss.339-350.

EŞKINNAT, Rana (2013), "Türkiye'de Kadına Yönelik Ekonomik Şiddet (Boşanmış Kadınlara Yönelik Araştırma)", Dumlupınar Üniversitesi Sosyal Bilimler Dergisi, S.37, ss.289-302.

FAWOLE, Olufunmilayo (2008), "Economic Violence to Women And Girls", Trauma Violence Abuse Online First, S.9(3), ss.167-177.

GENÇ, Yusuf, ALTIPARMAK, İpek Beyza ve USTABAŞI GÜNDÜZ, Dilara (2019), "Kadına Yönelik Şiddetin Erkekler Tarafindan Değerlendirilmesi: Sakarya Örneği", Afyon Kocatepe Üniversitesi Sosyal Bilimler Dergisi, S.21(2), ss.391-408.

GULJAN, Dönmez, ŞİMŞEK, Hatice ve GÜNAY, Türkan (2012), “Evli Erkeklerde Eşlerine Yönelik Şiddet ve Iliş̧kili Etmenler”, Türkiye Halk Sağlığı Dergisi, S.10(3), ss.151-159.

GÜLPINAR, Dilara Balcı ve KANDEMIRCI, Duygu (2013), “Evimin Kadını, Çocuklarımın Anası: Emekçi Kadına Yönelik Aile İçi Şiddetin Türkiye Sinemasındaki Sunumu”, Nişantaşı University Journal Of Social Sciences, S.1(1), ss.28-44.

GÜRKAN, Özlem ve COŞAR, Fatma (2009), “Ekonomik Şiddetin Kadın Yaşamındaki Etkileri”, Uluslararası Disiplinlerarası Kadın Çalışmaları Kongresi Bildiriler Kitabı, 5-7 Mart, Sakarya.

HACETTEPE ÜNIVERSITESI NÜFUS ETÜTLERI ENSTITÜSÜ (2003), Türkiye Nüfus ve Sağlık Araştırması (TNSA), Hacettepe Üniversitesi Yayını, Ankara.

HAN ALMIŞ, Behice, KOYUNCU KÜTÜK, Emel, GÜMÜŞTAŞ, Funda ve ÇELIK, Mustafa (2018), "Kadınlarda Ev İçi Şiddet İçin Risk Faktörleri ve Ev İçi Şiddete Uğrayan Kadınlarda Ruhsal Bozulmanın Belirleyicileri", Nöro Psikiyatri Arşivi, S.55, ss.67-72.

HARCAR, Tijen, ÇAKIR, Özlem, SÜRGEVIL, Olca ve BUDAK, Gönül (2008), "Kadına Yönelik Şiddet ve Türkiye’de Kadına Yönelik Şiddetin Durumu", Toplum ve Demokrasi Dergisi, S.2(4), ss.51-70.

HİNDIN, Michelle ve ADAİR, Linda (2002), "Who's at Risk? Factors Associated with Intimate Partner Violence in the Philippines", Social Science and Medicine, S.55, ss.1385-1399.

İÇLİ, Tülin Günşen (1994), "Aile İçi Şiddet: Ankara - İstanbul ve İzmir Örneği", Hacettepe Üniversitesi Edebiyat Fakültesi Dergisi, S.11(1-2), ss.7-20.

KAZGAN, Gülten (1979), "Türk Ekonomisinde Kadınların Işs Gücüne Katılması, Meslek Dağılımı, Eğitim Düzeyi ve Sosyo-Ekonomik Statüsü", Türk Toplumunda Kadın (Ed. Nermin ABADAN UNAT), Sosyal Bilimler Yayın1, Ankara, ss.155-189.

KERNIC, Mary A., WOLF Marsha E., HOLT Victoria L., McKNIGHT Barbara, HUEBNER, Colleen E., RIVARA, Frederick P. (2003), "Behavioral Problems Among Children Whose Mothers Are Abused By An Intimate Partner", Child Abuse Negl, S.27, ss.1231-1246.

KILIÇ, Dilek ve ÖZTÜRK, Selcen (2014), “Türkiye'de Kadınların İş Gücüne Katılımı Önündeki Engeller ve Çözüm Önerileri: Bir Ampirik Uygulama”, Türkiye Amme İdaresi Dergisi, S.47(1), ss.107-130.

KORKMAZ, Adem ve KORKUT, Gülsüm (2012), “Türkiye'de Kadının İşgücüne Katılımının Belirleyicileri”, Süleyman Demirel Üniversitesi İktisadi ve İ́dari Bilimler Fakültesi Dergisi, S.17(2), ss.41-65.

KÖSE, Aslı ve BEŞER, Ayşe (2007), "Kadının Değiştirilebilir Yazgısı "Şiddet”", Atatürk Üniversitesi Hemşirelik Yüksekokulu Dergisi, S.10(4), ss.114-121.

KRUG, Etienne, DAHLBERG, Linda, MERCY, James, ZWI, Anthony, ve LOZANO, Rafael (2002), World Report on Violence and Health, World Health Organization, Geneva.

KUZGUN, Yıldız ve SEVİM, Seher (2004), "Kadınların Çalışmasına Karşı Tutum ve Dini Yönelim Arasındaki İlişki", Ankara Üniversitesi Eğitim Bilimleri Fakültesi Dergisi, S.37(1), ss.14-27.

ÖKTEN, Şevket (2009), “Toplumsal Cinsiyet ve Iktidar: Güneydoğu Anadolu Bölgesi'nin Toplumsal Cinsiyet Düzeni", Uluslararası Sosyal Araştırmalar Dergisi, S.2(8), ss.302-312. 
ÖZÇATAL, Elif Özlem (2011), "Ataerkillik, Toplumsal Cinsiyet ve Kadının Çalışma Yaşamına Katılımı", Çankırı Karatekin Üniversitesi İktisadi ve İdari Bilimler Fakültesi Dergisi, S.1(1), ss.21-39.

ÖZTÜRK, Özlem, ÖZTÜRK, Özkan ve TAPAN, Birkan (2016), "Kadına Yönelik Şiddetin Kadın ve Toplum Sağllğı Üzerine Etkileri", Sağlık Akademisyenleri Dergisi, S.3(4), ss.139-144.

PAGANO, Marcello ve GAUVREAU, Kimberlee (1993), Sampling Theory, Duxbury Press, California.

RİGER, Stephanie ve KRIEGGLTEIN, Maryann (2000), "The Impact of Welfare Reform on Men's Violence against Women", American Journal Of Community Psychology, S.46, ss.631-647.

STEWART, Donna E. ve ROBINSON, Gail Erlick (1998), "A Review of Domestic Violence And Women's Mental Health", Arch Womens Ment Health, S.1, ss.83-89

SUBAŞI, Nüket ve AKIN, Ayşe (2011), "Kadına Yönelik Şiddet; Nedenleri ve Sonuçları", Hacettepe Üniversitesi Kadın Sorunları Uygulama ve Araştırma Merkezi (HUKSAM) Kurumsal Web Sayfası, http://www.huksam.hacettepe.edu.tr/Turkce/SayfaDosya/kadina_yon_siddet.pdf (Erişim Tarihi: 03.06.2019).

T. C. BAŞBAKANLIK KADININ STATÜSÜ GENEL MÜDÜRLÜĞÜ (2014), “Türkiye'de Kadına Yönelik Aile İçi Şiddet Araştırması”, E-Rapor, http://tkaa2014.kadininstatusu.gov.tr/

TATLI, Halim ve KOÇ, Beşir (2017), "Çalışan Kadın Bakış Açısıyla Kadınların İş ve Aile Yaşamında Karşılaştığı Sorunlar Hakkında Bir Uygulama", İktisadiyat Dergisi, S.1(1), ss.145-170.

THOMPSON, Linda ve WALKER, Alexis (1989), "Gender in Families: Women and Men in Marriage, Work, and Parenthood", Journal of Marriage and The Family, S.51(4), ss.845-871.

TNSA - HACETTEPE ÜNIVERSITESİ NÜFUS ETÜTLERİ ENSTITÜSÜ (2004), 2003 Yılı Türkiye Nüfus ve Sağlık Araştırması Raporu, Hacettepe Üniversitesi Nüfus Etütleri Enstitüsü Yayını, Ankara, http://www.hips.hacettepe.edu.tr/pdf/TNSA2003-AnaRapor.pdf (Erişim Tarihi: 03.06.2019).

TUIK - TÜRKIYE İSTATİSTIK KURUMU (2019), "Kadına Yönelik Aile İçi Şiddet", E-Rapor, http://rapory.tuik.gov.tr (Erişim Tarihi : 15.11.2019).

ULUOCAK, Şeref, GÖKULU, Gökhan ve BİLİR, Olgun (2014), "Kadına Yönelik Şiddetin Önlenmesinde Stratejik Bir Başlangıç Noktası: Partner Şiddeti", International Journal of Human Sciences, S.11(2), ss.362-387.

WHO - WORLD HEALTH ORGANIZATION (2005), Multi-Country Study on Women's Health And Domestic Violence Against Women: REPORT - Initial Results On Prevalence, Health Outcomes And Women's Responses, WHO Publications, Geneva.

YANIK, Aygül, HANBABA, Zeynep, SOYGÜR, Sevinç, AYALTI, Büşra ve DOĞAN, Meral (2014), "Kadına Yönelik Şiddet Davranışlarının Değerlendirilmesi: Türkiye'den Kanıt”, Electronic Journal of Vocational Colleges, S.4, ss.104-111.

YAVAŞ, Dilek ve ERSOY, Ali Fuat (2016), "Kadına Yönelik Şiddet ve Sosyal Hizmet", Karınca Kooperatif Postası, S.83(960), ss.3-10.

YILDIRIM, Ali ve ŞİMŞEK, Hasan (2008), Sosyal Bilimlerde Nitel Araştırma Yöntemleri, Seçkin Yayınları, Ankara.

YILMAZ, Emel Bahadır ve ÖZ, Fatma (2017), Kadın Hastaların Ekonomik Şiddete Ilişkin Deneyimleri ile Kadının Çalışmasına Yönelik Tutumları”, Balikesir Sağlik Bilimleri Dergisi, S.6(3), ss.97-103. 